\title{
Kurtuluştan Mondros Mütarekesi’ne Elviye-i Selâse'de Yaşanan Sorunlar
}

\begin{abstract}
Doç. Dr. Selçuk URAL *
$\ddot{O}_{z e t}$

Elviye-i Selâse, Rus yönetimde kaldı̆̆ süre boyunca hayatın her alanında büyük değişim geçirdi. Bu süreçte Türkler bir yandan göçe, diğer yandan hükümetin geri bırakmayı hedefleyen eğitim, kültürel ve iktisadi politikalarına karşı mücadele etmek zorunda kald.

3 Mart 1918'de imzalanan Brest-Litovsk Antlaşması Türk-Rus ilişkilerinin hem de bölgenin seyrini değiştirdi. Antlaşmanın dördüncü maddesi bölgenin ilhakını öngörüyordu. 1918 baharında gerçekleştirilen halk oylaması ilhakı resmileştirirken Osmanlı Devleti'ni de Kafkasya'da önemli bir aktör haline getirdi.

Yeni dönemde mülki teşkilatın kurulması, halkın refahının artırılması ve bazı askeri ve idari muafiyetlerin tanınması hükümetin öncelikleri arasinda yer ald. Hükümetin aldı̆̆ önlemelerin çoğu mülki teşkilatın gerektiği gibi tesis edilememesinden dolayl zaylf kaldl. Osmanl Devleti'nin Kafkasya'da iddial olmasını sağlayacak programlar ise savaş şartlarından ötürü hazırlanamadl.

Anahtar Kelimeler: Elviye-i Selâse (Kars, Ardahan, Batum), Osmanlı Devleti, Rusya, Kafkasya, Brest-Litovsk Antlaşması.

\section{The Problems Occurred in Three Provinces From Independence War to Mondros Armistice}

Abstract

During the period when three provinces were under the rule of Russians, they radically changed in every aspect of life. Turks were resisting to the immigration on the one hand they struggled with preventions of the government in educational, cultural, and economical fields.
\end{abstract}

*Kafkas Üniversitesi, Fen-Edebiyat Fakültesi Tarih Bölümü, Kars, sural25@hotmail.com. 
Brest-Litovsk Treaty, signed on $3^{\text {rd }}$ March 1918, changed the course of both the relationships of Turkish-Russians and the region. The $4^{\text {th }}$ article of the treaty envisaged the annexation of region to the Ottoman State. While the public poll held in the spring of 1918 made the annexation formal, it made Ottoman State an important actor in Caucassia.

The foundation of Civil Service, the increasing of the prosperity of the people, the recognition of some military and governing exemptions took place as priorities in the new period. Most of the precautions taken by the government were not effective because of not founding the civilian foundations appropriately. Programs that made the Ottoman State challenging were not prepared because of the war conditions.

Key words: Three Provinces (Kars, Ardahan, Batum), Ottoman State, Russia, Caucasia, Brest-Litovsk Treaty.

\section{Giriş}

Elviye-i Selâse/Üç Sancak, 93 Harbi denilen 1877-1878 Osmanl1-Rus Savaşı'nın ardından imzalanan Berlin Antlaşması'yla savaş tazminatı olarak Rusya'ya bırakılmıştı. Antlaşmanın yürürlüğe girmesiyle bölgenin mülki, sosyal, kültürel ve iktisadi yapısında hızla değiştirildi. 1877 tarihli Osmanlı devlet salnamesine göre Kars ve Ardahan Erzurum, Batum ise Trabzon vilayetine bağlı iken ${ }^{1}$, ilhak1 takiben Üç Sancak, merkezi Tiflis olan Zakafkasya Genel Valiliği'nin bir parçası haline getirildi. Batum ve Artvin Tiflis vilayetine, Kars sancağı ise oblast şeklinde teşkilatlandırılarak doğrudan genel valiliğe bağlandı. Buna göre Kars oblastı Kars, Kağızman, Ardahan ve Oltu kazalarından meydana geliyordu².

Batum ticari yatırımlar sayesinde Karadeniz havzasının önemli liman kentlerinden biri halini aldı. Trabzon-Erzurum-Tebriz tarihi ticaret yoluna karş1ık Batum-Tiflis-Tebriz hattı devreye sokularak Batum'u Kafkasya ve İran'ın ihracat merkezi haline getirildi ${ }^{3}$. Kars ise Güney Kafkasya demiryolu

\footnotetext{
${ }^{1}$ Selçuk GÜNAY, Resmi Devlet Salnamelerine Gore Osmanlı Imparatorluğu'nun Seneler İtibariyle Mülki Teşkilatı, (Yayınlanmamış Yüksek Lisans Tezi), Erzurum 1980, s.144, 147.

2 İlber ORTAYLI,"Çarlık Rusyası Yönetiminde Kars”, Tarih Enstitüsü Dergisi, Sayı: IX (Ayr1 Basım), İstanbul 1978, s.345.

3 TANIN, 16 Nisan 1334/1918, Nr: 3357; Ati gazetesinin 13 Mart 1918 tarihli nüshasında yer alan "Kars, Ardahan, Batum” adlı makalede Batum hakkında şu bilgiler yer almaktaydı: “... Batum Kafkasların ve Orta Asya'nın Karadeniz'e açılan penceresi olup Odesa ve İstanbul'dan sonra Karadeniz'in ü̧̧üncü önemli limanıdır. Batum üzerinden her yıl 50-60 milyon pud (bir pud yaklaşık 13 okkadır) ihracat yapılmaktaydl. Bunlar içinde gaz yă̆l, manganez, yün, pamuk ve misır gibi hububat öncelikli yer tutmaktaydl. Rus sermayedarlardan
} 
şebekesine dahil edilmesine karşın Trabzon veya Batum'la doğrudan bağlantı kuramadığından bölgeyle tam olarak bütünleşemedi. Osmanlı devrinde Anadolu'nun, Rus devrinde ise Kafkasya'nın uç noktası olmaktan öteye geçemeyen Kars şehri bundan ötürü sosyal, kültürel ve iktisadi yönden geri kalmışlık çemberini kıramadı.

Bölge işgal yıllarında yoğun Ruslaştırma ve hıristiyanlaştırma faaliyetlerine maruz kaldı. Rus yönetiminin politikaları sonucunda ilk üç yıl içerisinde 82.000 Türk, topraklarını terk ederek Osmanlı devletine sığındı. Boşalan veya boşaltılan köy ve kazalara Çarlığın muhtelif yerlerinden getirtilen ve aşağı yukarı tamamı hıristiyan olan ahali yerleştirildi. 1876 yılı Osmanlı nüfus sayımına göre; Kars, Ardahan ve Oltu'nun erkek nüfusu 39.257 (5.165'i gayri müslim) idi. Buna kadın, çocuk ve yazılmayanlar dahil edildiğinde toplam nüfus 100.000'i buluyordu. 1897 sayımında rakam 292.498'e çıkmıştır. Artış kolonizasyondan kaynaklanıyordu ${ }^{4}$.

1918'de Ati gazetesinde İbrahim Hilmi Bey tarafindan kaleme alınan “Kafkasya Hakkında Erkâm” adlı makalede Batum'un nüfusu 183.100, Kars sancağının nüfusu ise 396.200 gösteriliyordu ${ }^{5}$. Türklerin muhtelif nedenlerden ötürü göç ettiği dikkate alındığında nüfus dengesinin gayri müslimler lehine değiştirildiği söylenebilir. Nüfus ve sosyal yapıda başlayan değişim kırk yıl boyunca hayatın her alanında kendini hissettirerek sancakları Türk-İslam kimliğinden uzaklaştırmayı hedefleyecekti ${ }^{6}$.

birçoğu Batum'da kibrit, şeker, makarna, sabun fabrikaları ve değirmenler vücuda getirmişler, petrol depoları inşa ettirmişlerdi...” ATİ, 13 Mart 1334/1918, Nr:72.

4 ORTAYLI, “Çarlık Rusyası Yönetiminde Kars”, s.348.

5 ATI, 7 Mart 1334/1918, Nr: 66.

${ }^{6}$ Bölgedeki değişimden eğitim alanı da etkilendi. 1876-1877 yılı sayımına göre Kars, Kağızman ve Çıldır'da bulunan 3 rüş̧diye (ortaokul) sancağın en yüksek eğitim kurumlarıydı. Çarlık yönetimi 1898 'e kadar Kars'ta lise veya ortaokul açmadığı gibi, eğitime ayırdığı bütçe Dağıstan'la birlikte Kafkasya'daki en düşük bütçe olma özelliğini taşıyordu. Böyle bir manzaranın arkasında coğrafi nedenlerden ziyade bilinçli ve sistemli bir cehalet politikasının uygulanması yatıordu. 1905'te Rusya'nın Japonya'ya yenilmesinden sonra yapı değişmeye başladı. O güne kadar anavatandan sadece "Kuran-1 Kerim ve Mevlid" kitapları getirebilen Karslılar, yeni dönemde Kırım ve Azerbaycan gazetelerini temin eder bir hale geldiler. 1910'a gelindiğinde 12 devlet okuluna karşılık, 143 müslüman okulu faal haldeydi. Rus menşeli laik eğitimin gelişmemesinin arkasında Türk kesiminin muhalefeti de önemli bir rol oynuyordu. Muhalefetin liderliğini Evliya cami imamı Molla Muhyiddin Efendi ile Yusuf Zülâlî Efendi yapıyordu. Molla Muhyiddin Efendi cami ve evini okula dönüştürürken, Yusuf Zülâlî Efendi ise kaleme aldığı yazılarıyla halkın milli duygularını canlı tutmayı çalışıyordu. İlber Ortaylı, Rus yönetiminin 1858 Osmanlı Arazi Kanunnamesi'ni kendi mülkiyet düzeniyle bağdaştırdığını, Fahrettin Kırzıoğlu ise Rusların kendi arazi nizamnamesini tatbik ederek Türk halkının mülkiyetini en aza indirdiğini iddia etmektedir. ORTAYLI, “Çarlık Rusyası Yönetiminde Kars”, s.358; Fahrettin KIRZIOĞLU, Kars Tarihi, İstanbul 1953, s.553. 


\section{1- Elviye-i Selâse'nin Kurtuluşu}

1914'te başlayan Birinci Dünya Savaşı zaman içinde hem doğu vilayetlerinin, hem de Elviye-i Selâse'nin geleceğini önemli ölçüde etkiledi. 3. Ordu'nun Sarıkamış'a yönelik harekâtı başarısızlıkla sonuçlanınca doğu vilayetleri 1915-1916 yıllarında Rus istilasına uğradı. 1917'de patlak veren Bolşevik İhtilali hem Çarlık yönetiminin, hem de Osmanlı devletinin coğrafi ve siyasi geleceğini değiştirdi ${ }^{7}$.

Sovyet Hükümeti'nin ilhaksız ve tazminatsız barış sloganıyla başlattığ barış görüşmeleri 3 Mart 1918'de Brest-Litovsk Antlaşması'yla sonuçlandı. Antlaşma Çarlığın yıkılışını tescillerken, Osmanlı devletine de işgal altındaki vilayetleri kurtarma firsat1 yaratt ${ }^{8}$. Brest-Litovsk'un 4. Maddesi Rus ordusunun Elviye-i Selâse'yi tahliye ve ahaliye kendi kaderini belirleme hakkı tanıyordu. Bu madde sayesinde Rusya araziyi terk ve tahliye etmeyi kabul ettiğinden hukuki hâkimiyeti tamamen sona erdi. Dolayısıyla Osmanlı Devleti bölgenin mukadderatını belirlemede fevkalade önemli bir üstünlük elde etmiş oldu'.

Brest-Litovsk Antlaşması ile Rusya, 1878 sınırına dönerken, Osmanlı devleti de onun boşluğunu doldurmaya hazırlanıyordu. Kafkasya'ya yönelik düzenlemelerle Rusya'nın emperyalist emellerine ilelebet set çekilerek Anadolu garanti altına alma firsatı yakaland $1^{10}$.

Rusya işgal altındaki Vilayât-1 Şarkiye ve Elviye-i Selâse'yi muntazaman tahliye ve Taşnak çetelerinin faaliyetlerini durdurarak asayişi temin etmeği üstlendiği halde sorumluğunu yerine getirmemesi Türk ordusuna 4. Madde'nin tatbikini bizzat üstlenmesine yol açtı ${ }^{11}$. 3. Ordu 12 Şubat 1918'de ileri harekât başlattı. 13 Mart sabahı Erzurum'u kurtaran Türk ordusu, Elviye-i Selâse'ye girmek üzere önemli bir köprübaş1 elde ederken Büyük Ermenistan Projesi'ne de kesin bir darbe indirdi ${ }^{12}$.

7 Akdes Nimet KURAT, Türkiye ve Rusya, Ankara 1990, s.325; Oskar ANWELLER, Rusya'da Sovyetler (1905-1921), Çev: Temel Keşoğlu, İstanbul 1990, s.62.

8 VAKİT, 5 Mart 1334/1918. Nr:135; Selami KILIÇ, Türk-Sovyet İlişkilerinin Doğuşu, İstanbul 1998, s.77-79.

9 BOA, HR. HMŞ. İŞO, 107/10; Elviye-i Selâse'nin kurtarılacak olması devletin en batı noktalarından biri olan Peşte'den dahi hükümete tebrik telgrafı gönderilmesine vesile oldu. Peşte Başşehbenderi 8 Mart 1918 'de Sadaret'e gönderdiği telgrafta antlaşmayı büyük bir başarı olarak nitelendirerek ahalinin Elviye-i Selâse'nin kurtarılmasını sabırsızlıkla beklediğini ifade ediyordu. BOA, Ali Fuat Türkgeldi'nin Mirasçılarından Satın Alınan Belgeler Kataloğu, 6-57.

${ }^{10}$ TANIN, 13 Mart 1334/1918, Nr: 3324.

${ }^{11}$ BOA, HR. HMŞ. İŞO, 107/10.

12 ATI, 13 Mart 1334/1918, Nr: 72; Sovyet hükümetinin barış antlaşmasından kaynaklanan sorumluluklarını yerine getirmediği gibi, Ukrayna ve Finlandiya'ya saldırması Kafkas 
6 Nisan'dan itibaren gazeteler Elviye-i Selase'deki harekâta yer vermeye başladı. Ati gazetesi bu tarihte resmi tebliğe dayanarak Sarıkamış ile Ardahan'ın kurtarıldığını ve Batum istikametinde eski hududun geçildiğini, 7 Nisan'da ise düșmanın Kars istikametinde çekildiğini duyurdu ${ }^{13}$. $\quad 13$ Nisan'da Batum'a girilmesiyle Elviye-i Selâse'nin kurtuluşunda önemli bir merhale katedildi. Kafkasya'nın mahreci durumundaki Batum'un ele geçirilmesi sırasında herhangi bir taşkınlığa ve yağmaya mahal verilmedi. Şehrin ileri gelenlerinden oluşan bir heyet orduyu karşılayarak şehrin ve limanın mukavemetsiz alınmasına vesile oldu ${ }^{14} .16$ Nisan tarihli Sabah gazetesi "Batum İstirdad Edildi", başlıklı yazıda ordunun başarısına dikkat çekerek Rusların inşa ettiği kuvvetli tabyaların sırayla düşürüldüğü ve çok miktarda esir ve mühimmatın ele geçirildiği ifade ediliyordu ${ }^{15}$. Tanin gazetesinde yer alan "Batum Alındı" başlıklı haberde Batum'un yakın tarihi hakkında bilgiler verilerek Artvin ve çevresinin de katılımıyla Batum'un öneminin artacağ vurgulanıyordu $^{16}$.

cephesinde de her an farklı bir yola girebileceği endișesini doğuruyordu. Ahmet Emin Bey Vakit'te kaleme aldığı "Rusya İle Harp" adlı makalede bu endişeye yer vermekte birlikte Alman ve Avusturya ordularının Rusya'yı kısa süre içinde yola getireceğine inanmaktaydı. VAKITT, 20 Nisan 1334/1918, Nr: 180.

${ }^{13}$ ATİ, 6 Nisan 1334/1918, Nr: 96; ATİ, 7 Nisan 1334/1918, Nr: 97.

${ }^{14}$ ATİ, 16 Nisan 1334/1918, Nr: 106.

${ }^{15}$ SABAH, 16 Nisan 1334/1918, Nr:10208.

16 Yazıda şöyle denilmekteydi: "1877 Osmanl-Rus muharebesinden evvel Lazistan sancağının merkezi iken, Berlin Muahedenamesi mucibince muvakkaten Rusya'ya terk edilmiş olan Batum bu eski muharebede de Türk kahramanlığına şahid olmuş, Ruslar bu güzel şehri zapt için ilerlemişlerse de muvaffak olamamışlar, sonra bil-mecburiye şehir Ruslara bırakılmıştır. Sultan Abdülaziz zamanında Trabzon Valisi Emin Muhlis Paşa'nın himmetiyle civardaki bataklıklar tathir ve şehir ıslah ve imar edilmiş ve "Aziziye" namıyla büyük bir camide yapılmıştı. Ruslar zamanında şehir daha ziyade tevessü etmiş daha da güzelleşmiş, muntazam caddeler açılmış büyük ve umumi bahçeler vücuda getirilmişti. Şehrin tahkim edilmemesi Berlin Muahedenamesi ahkâmından olmasına rağmen Batum mükemmel bir harp limanı haline konulmuştur. Batum, Karadeniz'in kısm-l şarkiyyesinde Kafkasya sahilinin mühim bir liman haline getirilmeye en müsait olan yeridir. Biraz daha şimalde vaki (Poti) bataklıklar içinde bulunması ve büyük gemilerin takarrübüne imkân vermemesi itibarlyla hiç işe yaramayan bir yerdir. Batum limanına en büyük gemiler bile sokulabilir. (Poti) ve Tiflis tarikiyle Bakü'ye giden demir yolunun hitam-ı inşasindan sonra bu liman bir kat daha ehemmiyet kesb etmiş ve Kafkasya'nın mühim bir ihracat limanı olmuştur. Bu liman petrolden maada hayvanat, pamuk, meyve ve yunus balı̆̆ından çıkarılan yă̆ ihraç eder. Fakat Batum'un faaliyet-i ticariyesi Tiflis- Bakü Demiryoluna malik olmaksızın da tezayüd edilebilir. Çoruh vadisinin ve buna gelip karışan tabii nehirlerin kuvve-i inbaniyesi parlak olan topraklar Batum vasitasıyla ihraç olunacak hâsılatı yetiştirmeye müsaittir. Bilhassa Çoruh doğrudan doğruya limana rabt edilecek olursa şehrin arkasındaki zengin memleket ile rabıtası daha mükemmel bir şekle konulmuş olur. Çoruh nehri üzerinde seyr-ü seferin güçlügüne ve tehlikesine rağmen bunlardan da istifade edilmelidir... Batum limanına kesb ettiği ehemmiyet şehir nüfusunun pek ziyade tezayüdünü mucip olmuştur. Evvelce 5-6 binden 
Batum'dan sonra artık sıra Kars'a geldi. Buna ilișkin beklenti iki hafta sonra gerçeğe dönüştü. Tahkimatlarından dolayı yanına bile yaklaşılamaz denilen Kars kalesi kısa sürede ele geçirildi ${ }^{17}$. Ati gazetesi "Kars'ın Zaptı" başlıklı haberde Brest-Litovsk sınırlarına ulaşıldığına dikkat çekiyordu ${ }^{18}$.

Kurtuluşu takiben Türk basını bölgenin sosyal, kültürel ve iktisadi sorunlarını gazetecilerin gözlemlerine dayanan haberlerle sütunlarına taşıdı. Celal Nuri Bey 20 Nisan 1918'de Ati gazetesinde kaleme aldı̆̆ 1 "Vilayât-l Şarkiye, Batum, Kars, Ardahan” başlıklı makalede hükümetin önünde doğu vilayetlerinin imarı ile Elviye-i Selâse'nin (Batum, Kars ve Ardahan) idaresi gibi iki önemli görevin bulunduğunu belirterek, öncelikle ahalinin savaş zararlarının telafisi için hazinenin vilayetlerin varidatını bir müddet bölgeye harcamasını ve İtibar-1 Milli ve Ziraat Bankası'nın halka yardım elini uzatmasını teklif ettikten sonra eğitimden başlamak üzere hayatın her alanında yeni planlara ihtiyaç duyulduğunu vurguladı. Celal Nuri Bey'e göre 40 yıllık Rus yönetimi bölgenin sosyal, kültürel ve iktisadi yapısını ciddi şekilde değiştirmişti. Bu nedenle hükümet Kars, Batum, Ardahan'ın idaresine özel önem vermeliydi. Celal Nuri Bey, Bakü petrollerinin demiryoluyla Batum'a ulaştırılmasının şehri iktisaden kuvvetlendirdiğini, limanın Kafkasların Karadeniz ve Avrupa'ya açılan yegâne penceresi olduğunu belirtiyordu. Batum'un iktisaden korunması ve kuvvetlendirilmesi için gerekirse yeni iktisadi imtiyazlar verilmesini, Rus yönetiminin doğru uygulamalarına devam edilmesini önerirken bunu yaparken sosyal yapının daha fazla bozulmamasına dikkat edilmesini istiyordu. Elviye-i Selâse'de yapılacaklar Kafkasya'nın Osmanlı Devleti ile ittihadına veya hiç olmazsa ittifakına zemin hazırlamalıydı. Hükümet buna yönelik tedbirlerini gecikmeden almalıyd ${ }^{19}$.

Fazıl Ahmet Bey Sabah gazetesinde "Batum Yolculuğu” adıyla tefrika edilen yazı dizisinde ilk olarak eğitim sorununu ele alarak ciddi atılımın yapılması gerektiğine işaret etti. Türkçenin silinmekte olduğuna dikkat çeken yazar makalenin devamında şöyle diyordu: "Orada Ruslar bizden ne varsa kazımışlar. Lakin kendilerinden hayli mühim esaslar bırakmıştır. Onlar

ibaret olan nüfus en son istatistiklere nazaran 45 bine yaklaşmıştır. Nüfusunun ekseriyet-i azimesi Müslüman-Türk olan bu sevimli limanın Türk kucağına avdet etmesi gögüslerimizi büyük bir gurur ve sevinç ile kabartmaktadır". TANIN, 16 Nisan 1334/1918, Nr: 3357.

17 SABAH, 27 Nisan 1334/1918, Nr:10219.

${ }^{18}$ Haberin devamında Kars kalesinin Anadolu'nun gururu olduğu vurgulanarak Çarlığın pek mühim bir mevkide bulunan bu kale vasitasiyla Erzurum, Elazığ ve Adana üzerinden İskenderun Körfezi'ne inmeyi hedeflediği, fakat kaderin başka şekilde tecelli ederek hem rrki, hem tarihi, hem dini, hem de coğrafi açıdan Anadolu kıtasına ait olan Elviye-i Selâse'nin gerçek sahiplerine kavuştuğu ifade edildi. ATİ, 27 Nisan 1334/1918, Nr:117.

${ }^{19}$ ATİ, 20 Nisan 1334/1918, Nr: 110. 
geçmişten geleceğe doğru tehditle uzanan birer kol demektir. Ordumuz, bayrağımı kalelere şeref verdiği gibi iktisadiyemiz de bankaların karşısında yüksek bir alın gösterecek mi? Maarifimizin muvaffakiyetleridir ki bugün kucă̆ımızda Batum'a hakiki bir ana şefkatiyle bağlı olduğumuzu ispat edecek, maarifimizin hemen oraya koşması ne kadar lazım ne kadar!"20.

Fazıl Ahmet Bey, "Batum Trabzon'u Unutturmamalı" başlıklı makalesinde ise Batum-Trabzon karşılaştırması yaparak Trabzon'un Batum'a tercih edilmemesini salık veriyordu: "Şimdiye kadar çok mazarratın gördüğümüz kusurlarımızdan biri de yeni hevesliliktir. Batum'u aldik diye Trabzon'u unutmamallyı. Nemiz varsa nemiz yoksa Batum'a gönderiyoruz. Batum ahalisine işgalimizi, eski sahiplerinin işgalinden lehimize olarak farklı göstermeliyiz. Bu gayet âli şayan-ı hürmet bir arzudur. Kaybetmiş olup kavuştuğumuz bir çocuğumuzu okşar, öper, bir vakit için mesaimizi, muhabbetimizi bütün ona vakfedebiliriz. Fakat bu tabii sevinç, emekdarımız, muhabbetkârımız olan diğer ekber evladımızın ehemmiyetine katiyen nakize getiremez ve getirmemelidir. Birçok emek sarf edildikten sonra bize hazır olarak terk edilen Batum limanının elimize geçmesiyle Trabzon'u ihmal etmek Asya siyaset-i iktisadiyemiz ve hariciyemiz nokta-i nazarından pek büyük bir hata teşkil eder" ${ }^{21}$.

Bölgeye ilişkin yazıları artırmak mümkündür. Fakat burada yer verilen makalelerle bile bölgenin sorunları hakkında önemli ipuçları elde edilebilmektedir. Vilayetler arasında uyum ve dengenin korunması gerektiği anlayışından yola çıkıldığında hükümetin öncelikleri mülki idarenin tesisi, bölgedeki eğitim ve iktisadi hayatın canlandırılarak sosyal yapının kuvvetlendirilmesi şeklinde sıralanabilir.

Mülki teşkilatın kuruluşuna geçmeden önce hükümetin gerek doğu vilayetleri, gerekse Elviye-i Selâse'ye yönelik aldığ 1 birkaç karara yer vermek doğru olacaktır. Bunlar içinde Türk ahaliye gerçekleştirilen mezalimin tespiti, Rus parasının tedavülde tutulması ve ahalinin tekâlif-i harbiyeden muaf tutulması sayılabilir.

Hükümetin ilk kararı işgalden kurtarılan yerlerde Rus ordusu ile Ermeni ve Rum çeteleri tarafından Türk ahaliye yönelik mezalimin tespit ve kayıt altına alınması oldu. Dahiliye Nezareti 24 Mart 1918'de söz konusu vilayet ve livalara gönderdiği telgrafta düşmandan hangi tarihlerde nerelerin alındığını, gerek Rus askeri ve gerekse Ermeni ve Rum çeteleri tarafindan

${ }^{20}$ SABAH, 29 May1s 1334/1918, Nr: 10251.

${ }^{21}$ SABAH, 4 Haziran 1334/1918, Nr: 10256. 
icra edilen cinayetlerin tespitiyle bu hususta alınan önlemlerin derhal bildirilmesini talep etti ${ }^{22}$.

Maliye Nezareti istiladan kurtarılan bütün vilayet ve sancaklarda Rus parasının kanun gereği toplatılarak imha edilmesinin ahalinin mağduriyetine neden olduğunu tespit ederek 11 Mayıs 1918 tarihi itibariyle söz konusu uygulamanın bir süre ertelenmesine karar verdi ${ }^{23}$.

16 Mayıs 1918 'de ise Rus işgalinden kurtarılan yerlerin tekâlif-i harbiyeden muaf tutulmasına karar verilerek gereği Harbiye Nezareti'nden talep edildi. Harbiye Nezareti aldığı emir doğrultusunda söz konusu vilayet ve sancakların istisna edildiğini 3. Ordu Komutanlığı'na bildirdi. Sadaret 14 Temmuz 1918'de Dahiliye Nezareti'ne ilgili mahallere lazım gelen tebligatın yapılmasını emretti ${ }^{24}$.

\section{2- Mülki Teșkilatın Tesisi}

Brest-Litovsk Antlaşmasının 4. Maddesi gereği Osmanlı devleti, tahliyenin ardından Elviye-i Selâse ahalisinin yeni yönetimi belirlemesi hususunda sorumluluk üstlenmiş̧i. Çünkü Rusya bölgeyi terk ve tahliye etmeyi kabul ettiğinden hukuki hakimiyeti son bulmuştu.

Üç sancağın geleceğini tayin ve ahalinin yeni bir idareyi tesisi mahalli idareye; dolayısıyla Osmanlı hükümetine havale edilmiş olduğundan öncelikle mülki teşkilatın kurulması için harekete geçildi. 1907 tarihli Lahey

22 BOA, DH/İ-UM, 20-18/12-24; Gerek doğu vilayetleri gerekse Elviye-i Selâse ahalisi Ermeni mezaliminden oldukça sıkıntı çekmiş olmasına karşın Kağızman kaymakamlığını yürütmekte olan Mülkiye Müfettişi Asaf Talat Bey 3 Aralık 1918'de Dahiliye Nezareti'ne gönderdiği telgrafta Elviye-i Selâse de dahil olmak üzere Ermenilerin eski topraklarına dönmelerine izin ve kolaylık tanınması durumunda hem hükümetin iyi niyetinin ibraz edilmiş olacağını, hem de Taşnakların maddi ve manevi kuvvetlerinin kırılacağına dikkat çekerek bu yolla sanat, ziraat ve ticarette zayıflamış olan memleketin yeniden ayağa kalkacağını savundu. BOA, DH/İ-UM, 20-20/13-35.

${ }^{23}$ BOA, DH/İ-UM, 20-18/12-49; Türk parasının zamanla Rus parasının yerini alması gerekirken Kasım ayında Batum'da ufaklık akçe bulmakta sıkıntı baş gösterecekti. Mutasarrıf Cemil Bey 13 Kasım 1918'de “yarım ve beşer liralık evrak-ı nakdiye gönderilmezse buhran karşısında kalacağız" sözleriyle dikkat çektiği sorunun Harbiye ve Maliye Nezaretleri ile İtibar-1 Milli bankasına tebligatta bulunulmasıyla aşılabileceğine inanmaktaydı. BOA, DH/İUM, 20-20/13-43.

${ }^{24}$ BOA, DH/İ-UM, 20-18/12-74; Elviye-i Selâse tekâlif-i harbiyeden muaf tutulan yerlerden addedilmesine karşın bu kapsamın dışında kalan vergilerden hangilerinin tahsil edileceğini içeren kararname Kasım ayına kadar çıkarılması mümkün olamadı. Kars mutasarrıf vekili Hilmi Bey 22 Kasım'da söz konusu kararnamenin yayınlandığına ilişkin haberlerin duyulduğunu belirterek bu hususta bilgi talep etti. Dahiliye Nezareti 25 Kasım'da Maliye Nezareti nezdinde girişimde bulunarak kararnamenin bir an evvel tebliğ edilmesini istedi. BOA, DH/I-UM, 20-20/13-29. 
Sözleşmesinin 43. Maddesinde "Hükümet-i meşruanın hüküm ve nüfuzu emr-i işgali icra eyleyen tarafin yedine geçmiş bulunacağından bu taraf bir mani olmadiğ halde memlekette cari kavain ve nizamata riayetiyle emr ve intizam ve halkın hayatın imkan olduğu mertebede iade ve temin için elden gelen bilcümle tedabiri ittihaz eyleyecektir" hükmü yer aldığından Osmanlı hükümeti üç sancak mukadderatının tayinine kadar kendi yönetimini kurma hakkını elinde bulunduruyordu ${ }^{25}$.

Hükümet bir yandan bölgenin Osmanlı devletine iltihakını temin edecek olan halk oylamasını, diğer yandan da yeni mülki idareyi tesis için Dahiliye Nezareti Müsteşarı Mustafa Abdülhalık Bey başkanlığında bir heyeti tertip ederek bölgeye gönderme kararı aldı. Hükümet idari alanda bu adımları atarken mülki teşkilatların kuruluşunu hızlandırmak ve memurların işgalden kurtarılan bölgelerde görev almalarını cazibeli bir hale getirmek üzere 1 Nisan 1918'de doğu vilayetleri için "Tahsisat-ı Fevkalade Kanunu" çıkardı. 26 Mayıs'ta Batum, Kars ve Ardahan livalarında görev alacak memurlara da kanundan yararlanma hakkı tanınd1 ${ }^{26}$.

Abdülhalık Bey'in başkanlık ettiği heyette Mülkiye Müfettişi Hilmi (Uran), Şakir (Kesebir), Asaf Talat ve Necati Beyler bulunuyordu ${ }^{27}$. Heyetin öncelikli görevi halkı aydınlatarak oylamanın sorunsuz şekilde yürütülmesini sağlamaktı. 12 Haziran 1918 'de başlatılan halk oylamasında ortaya çıkan sonuç hükümetin beklentilerini boşa çıkarmadı. Ahalinin büyük çoğunluğu Osmanlı yönetimini talep ederek bir yandan Osmanlı camiasına katılırken, diğer yandan da Türk mülki teşkilatının kurulmasının yolunu açtı ${ }^{28}$. Heyetin oylamaya ilişkin tanzim ettiği rapor ile yine oylamaya ait mahallerce tanzim edilen 62 kıta mazbata ve bir kita cetvel ile oy pusulalarının tutulduğu iki sandık Abdülhalık Bey tarafından Dahiliye Nezareti'ne gönderildi. Dahiliye Nezareti söz konusu rapor ve cetvelleri 28 Temmuz'da Meclis-i Vükela'ya havale etti. Meclis-i Vükela'da aynı gün vuku bulan görüşmede Dahiliye Nazırı İsmail, Adliye Nazırı Halil ve Maarif Nazırı Nazım Beyefendilerden bir encümen-i vükela teşkil edilerek iltihak meselesinin tayin şeklinin karara bağlanması yönünde görüş benimsendii ${ }^{29}$. Elviye-i Selâse'nin Osmanlı

\footnotetext{
${ }^{25}$ BOA, HR. HMŞ. İŞO, 107/10.

${ }^{26}$ BOA, MVM, 212/34.

${ }^{27}$ Abdülhalık Bey tanzim edilecek raporu sunmak üzere İstanbul'a dönecekken heyetin diğer üyeleri bölgede kalarak mülki idareyi tesis etmeye ve yürütmeye çalışacaklardı. Esin DAYI, Elviye-i Selâse'de (Kars, Ardahan, Batum,) Milli Teşkilatlanma, Erzurum 1997, s. 61.

${ }^{28}$ Geniş bilgi için bkz: Ender GÖKDEMIR, Cenûbî Garbî Kafkas Hükümeti, Ankara 1989, s.20-22, DAYI, Elviye-i Selâse'de (Kars, Ardahan, Batum,) Milli Teşkilatlanma, s. 60-65.

${ }^{29}$ BOA, MVM, 212/111.
} 
devletine katılımını öngören çalışmalar 15 Ağustos 1918'de tamamlandı. Sultan Vahdettin tarafindan çıkarılan fermanla bölge anavatana katıld ${ }^{30}$.

Abdülhalık Bey başkanlığındaki heyet aynı süre içinde mülki teşkilata ilişkin incelemelerini tamamlayarak elde ettiği sonuçları 30 Temmuz 1918 tarihli gayet geniş bir rapor halinde hükümete sundu. Yol haritasını niteliğinde sayılabilecek raporda bölgesel Rus yönetimi, yeni mülki teşkilat ve yapılması öngörülen düzenlemeler hakkında önemli tespit ve bilgilere yer veriliyordu:

Elviye-i Selase dâhilinde irae-i umumiyeye müracaat için devr-i güzâr eylediği sırada bir taraftan da Rusların teşkilat-ı idariyesi tedkik ve bilhassa teşkilat-l mezkurenin ekseriyet-i azimesi Íslamlara mahsus olan sekene-i mahalliye üzerinde kırk seneden beri hâsıl etmis olduğu intibaat-ı idareye tefahhus olunmakta idi. Tedkikat vukuuyla neticesinde Ruslartn Elviye-i Selâse dahilinde anasır-ı islamiyenin kesretine rağmen-Bulgar ve Romenler gibi- bunlar imha veya teb'ide teşebbüs etmek suretiyle milli bir idare siyaseti takip etmemiş olmakla beraber Rusya içerilerinden getirdikleri bir kısım Rus Malakanları öteye beriye yerleştirmiş ve diğer cihetten de beynelislam nifak ve tefrika ikası tarikiyle aynı din ve fakat muhtelif mezâhibe bağlı olan nüfus-l islamiyeden hükümete taraftar kazanarak Rusya idarelerini tanzim eylemiş oldukları anlaşılmıştır. Ancak şurası gayr-i kabil-i inkârdır ki Elviye-i Selâse'nin idaresindeki bu siyaset idare-i mezkûrenin maddi ve manevi ihtiyacat- irsiye ile telifini men etmemiş ve Rus hükümetince mezkûr livalar dâhilindeki bilumum kasabata muntazam şoseler inşası ve tahsis-i emniyet ve asayişin suret-i fevkalade de temin ve tesbiti ve Rusya'ya hisse-i intikalinde vehâmet-i havâiyesi ve ümrandan mahrumiyetle şehr-i bîtâb olan Batum'un bilumum bataklıkları teybis olarak bağçeler içinde mükemmel bir şehir haline getirilmiş olmakla beraber Karadeniz'inde ticari ve askeri mükemmel bir limanı haline isal edilmesi ve mülhakatta-oraların ahval-i umumisine dair takdim olan raporda tafsilat arz olunacağl vechileenva-i esbab-l ümrana tevessül kılınması bunu isbat eylemekte bulunmuştur.

Elviye-i Selâse dâhilinde müşahede edilen asar ve müessesat-l ümraniyeye rağmen Rusların burada tesis ettikleri idare bir idare-i nafia olub teşkilat-ı mülkiyeden ziyade taksimat-ı askeriyeye istihdaf eylemiştir. Filhakika Batum ve Kars vilayetleri Kafkasya Vali-i Umumiligi'ne tabi olmakla beraber münasebet-i askeriye itibariyle mümtaz bir surette idare edilmekte idiler.

${ }^{30}$ GÖKDEMIR, Cenûbî Garbî Kafkas Hükümeti, s.22; DAYI, Elviye-i Selâse'de (Kars, Ardahan, Batum,) Milli Teşkilatlanma, s. 65-67. 
Taksimat-ı Mülkiye- Rusların taksimatı ve cümle Elviye-i Selâse Kars ile Batum mintıkalarına münhasır olup bunlardan her biri vali-i umumilikle mutasarrıfllk arasinda bir dereceyi ve oblast-guvernatör ünvanını haiz birer vali-i askeri tarafindan idare olunmak ve Batum vilayeti Batum, Artvin kazalarını ve Kars vilayeti de; Kars, Ardahan, Oltu, Kağızman kazalarını ihtiva eylemektedir. Bunlardan Batum kazası; Çürüksu, Gönye, Aşağı Acara, Yukarı Acara namıyla dört, Artvin kazası; Nefs-i Artvin, Ardanuç, Şavşat ismiyle üç baş müdüriyete, Kars vilayetinin Kars merkez kazası; Nefs-i Kars, Zaruşat, Şöregel, Akbaba, Sarıkamış namıyla beş, Ardahan kazası; Nefs-i Ardahan, Göle, Poshof, Çıldır namılla dört, Oltu kazası; Nefs-i Oltu, Tavuskerd ismiyle iki ve Kağızman kazası da; Nefs-i Kağızman, Horasan, Nahçıvan namıyla üç ki, her iki vilayet cem'an 21 baş müdüriyete yani bizim kazalar derecesinde birer mıntıkaya ve her baş müdüriyet dahi 3 ila 8 okruk yani nahiyeye münkasım bulunmuş idi.

Memurin Vezaif ve Tavinleri - Bu mahallerden Batum ile Kars'ta birer vali bulunur ve bunlara ayrica birer muavin veriliyordu. Kaza merkezlerinde birer kaymakam ile ayrıa birer nahiye müdürü tayin edilmişti. Valilerin vazifesi vilayet, ma-mülhakat mesail-i umumiyesiyle iştigal ve muavinlerin vazifesi de yalnı merkez vilayet umurunu temşiyete münhasır eder. Kaymakamlar ile merkez kaza müdürleri de aynı suretle yani birincisi umum kaza umuruyla ve ikincisi merkez kazadaki hususat ile iştigal ederlerdi. Başmüdürler yani kaza kaymakamları hükümetçe tayin ve tevzif olunup okruk (nahiye) müdürleri taraf-l ahaliden intihab ve bunların maâşâtıyla maiyetindeki jandarma ve kâtiplerin mahsusatı yine ahali canibinden tesviye kllıniyor idi. İşbu okruklar zahiren komün gibi telakki ediliyorsa da hakikatte öyle değildir. Çünkü Ruslar, Rusya içerisinden celbettikleri halis Rus ve Malakanlarla meskûn ve bit-tabi mamur bulunan köylerin her birini veya ikisini bir nahiye itibar etmiş olduklar halde Elviye$i$ Selâse dâhilindeki kurranın ekseriyetini teşkil eden ve sanat-ı mevkiyeden dolay büyük köy halinde bulunan ve varidat itibariyle fakir bulunan İslam köylerinin 20-40 adedini birer okruk addettiklerinden bunlara komünden ziyade bizdeki nahiye ismi vermek daha muvafiktır.

Teşiklat-ı mülkiye Elviye-i Selâse'nin böylece her tarafina şamil olduğu halde hükümetin şuabât-ı sairesi teşkilatı muntazam değildi. Mesela Maliye teşkilatı yalnız Batum, Artvin, Kars, Ardahan, Oltu ve Kağızman'da mevcut olup diğer mahallerde maliye umuru ve tahsilât vezaifi mülkiye memurları tarafindan ifa ediliyor. Ve kezalik Adliye teşkilatı Batum ile Kars'a inhisar ettiğinden bilâd-ı sairede umur-ı adliye Baş müdüriyetler dahilinde dolaşan seyyar müdde-i umumilikler tarafindan tesviye olunurdu. Bundan dolayı balada arz olunduğu üzre idare-i umumiye nakîs bir halde idi. 
Kurra ve Nüfus Miktart- Teşkilat-ı ma'rûzanın bugünkü daire-i şümulünde 1.215'i müslim ve 39'u gayri müslim ve 19'u muhtelit olarak 1.273 karye bulunmakta ve kasabalar ile beraber bu karyeler 40.894'ü müslim ve 6.184'ü gayri müslim olmak üzere cem'an 47.078 haneyi ihtiva etmektedir. Buralardaki nüfusa gelince ara-i umumiyeye müracaat için her kazada yaptırtlan tahrir-i muvakkat neticesinde 274 bin müslim ve 46 bin gayri müslim olarak cem'an 320 bin nüfus teadad olunabilmiştir. Rusya ile ilan-ı harbi müteakib tarafimızdan vukubulan taarruz ve ricat esnasinda Ardanuç, Artvin, Gönye, Oltu ve Tavuskerd baş müdüriyetlerinden memalik-i asliye-i Osmaniye'ye iltica ve hicret etmiş olan ahali-i islamiye tamamen yerlerine avdet ettiği halde nüfus-ı umumiyenin bu miktarl da tecavüz edeceği ve ba'del- ilhak icrast derkâr olan tahrir-i nüfus ile kuyud-u kat'iyyenin istihsal edilmesi tabiidir.

Bizce Yapılması Muktezi Tesskilat- Arz olunan teşkilat-ı idariyenin hudutları harita üzerinde tetkik olunursa bu teşkilatın Ruslarca adeta teşkilat-ı tabiye-i araziye ve iklimiyeye tevfik edildiği anlaşıllyor. Filhakika idareten iki mintıkaya taksim edilmiş olan Batum ile Kars vilayetleri yüce dağlarla tefrik edilmiş ve bu dağlar Batum mıntıkasında sath-ı bahriden 500-600 metreyi tecavüz ettiği halde Kars cihetinde 1.500-2.000 metreden noksan olmamak üzere mevsim gayr-i kabil mürur irtifalarla teselsül ve tevâlî etmiştir. Hatta Batum vilayetinde bahar ve sayf icra-i hüküm ederken Kars tarafinda berf-ü baraniyle şiddetli bir kışın devam eylediği esna-i seyahatimizde bizzat müşahede eylemiş idi. Şu hale göre Rusların taksimat-l idaresini bizde kabul mecburiyetinde olduğumuzdan Elviye-i Selâse'yi evvela Batum ve Kars mintikalarina tefrik ve badehu sancak veya vilayet namıyla tevsim etmek lazım gelir.

Fikr-i acizanemce bu iki mintıkanın tefrikinden sonra Elviye-i Selâse dahilinde birisi Batum, diğeri Kars namıla iki vilayet veya müstakil liva teşkili muvafiktır. 6.219 verst yani 6.533 kilometre-i murabba mesâha-i sathiyyeyi havi bir arazi dahilinde 432 karyeyi ihtiva edecek olan Batum vilayeti; Çürüksu, Yukarı Acara, Aşă̆ı Acara, Orta Batum, Maradit, Borçka, Artvin, Ardanuç, Şavşat kazalarından ve 16.464 verst yani 17.550 kilometrei murabballk bir sahada 841 karyeyi ihtiva edecek olan Kars vilayetinde; Göle, Ardahan, Çıldır, Zaruşat, Şöregel, Akbaba, Nefs-i Kars, Sarıkamış, Ĭgdır, Kağızman, Nahçıvan, Oltu, Tavuskerd, Poshof kazalarından mürekkep olmalıdır. Kars'in kazalar meyanında Oltu ile Tavuskerd'in Kars 'tan ziyade Erzurum'a münasebet-i mevkileri olup Kars ile Erzurum ise her iki kazaya ba'del-müsavi olduğundan bu ikisinin Erzurum vilayetine raptı daha muvafiktır. Birde yine Kars'in Poshof kazası Ahıska'ya karib olduğu cihetle Ahıska'da teşkilat-ı mülkiye icra kılındığı halde oraya raptı münasip olur. 
İsbu kazaların cümlesi müteaddit nevahiye taksim edilmiştir. Batum vilayetinin serapa sengistan olması ve karyelerinin müteferrik ve kalîl olmakdar haneleri havi bulunması hasebiyle komün teşkilatının bu vilayette matlub-ı vechile tatbiki mümkün değilse de mesafe ve mevkii ve münasebet gözetilerek her nahiyenin 10 ila 20 köyden terkibi halinde bütünü manastyla olmasa bile mürekkeb birer komün teşkili mümkündür. Kars vilayetinde de köyler yekdiğerinden uzak ve haneler kalîl ve varidatça zaylf olması itibariyle komün teşkilatı aynen hal tatbik olunabilir.

Yollar- Arz-ı vaka olunan kazalar merakiziyle iki vilayet merkezi beyninde -yalnız Poshof ve Şavşat müstesna olmak üzere-kâmilen şose mevcuttur. Batum vilayeti dâhilindeki şoselerin tûlu 550 ve Kars vilayetindekilerin mecmua 1.073 kilometreye baliğ olunmaktadır. İki vilayet merkezinden en uzak kaza merkezinin mesafesi yüz kilometreyi tecavüz etmez. Şoseler Ruslar zamanında hüsn-ü halde muhafaza ve idame edilmiştir.

Memurin- Teşkilat-ı ma'rûza tatbik olunduğu halde memurin hakkında hatıra gelen nokta bunların ünvanıdır. Zira Ruslar o havalide daima büyük ünvanl memurlar bulundurarak idareye böyle nam ile bir azamet bahşeylemiş ve ahali de buna alışmış olduğundan Batum ve Kars'a gönderilecek reis-i idarenin vali namın haiz olması daha münasiptir. Mezkûr mahaller vilayet değil liva halinde olunduğu takdirde mutasarrıfların behemehâl müstakil olması birinci derecede nazır-ı dikkate alınacak mevaddandır. Mamafih bu takdirde de mutasarriflikların idare-i hususiyeleri ayrı olmak üzere her ikisinin fevkinde olarak (Kafkas Vilayeti Valisi) namıyla diğer büyük bir memurin Elviye-i Selâse dahilinde bulundurulması icap eder. Bu vali iki müstakil mutasarrıfliğn yalnız idare-i umumiyesine nezaret edecek ve Batum ve Kars müstakil mutasarriflar idare-i hususiyelerinde doğruca mezkûr hükümetle muhabere eyleyeceklerdir. Ahılkelek ve Ahıska ve Ĭgdır ile beraber Gümrü birer müstakil mutasarrıfllk halinde idare edileceği takdirde bu müstakil mutasarriflikların da ayn tarzda Kafkas vilayetine raptı muvafik olur.

Teşkilat-ı mahalliyeye dair Batum'dan sebk eden işarât-ı acizanemce de mezkûr olduğu vechile teklif olunan kazaların teşkili halinde yirmibir (21) kaymakamla, doksan (90) kadar nahiye müdürüne ihtiyacımız tahakkuk etmektedir. Bu kadar memurların suret-i tedariki ise muhtaç-l temil oyup fakat her takdirde iki şıktan hariç değildir. Birincisi bunlardan mümkün olanların mahalden, ikincisi memurin-i mevcuda-i devlet meyanında intihab ve tefrikidir. Birinci şıkkın halen ihtiyarına imkân görememekteyim. Zira Ruslar Elviye-i Selâse dâhilinde ekseriyet-i azimeyi teşkil eden müslümanlar arasında ittihad husulünü men için daima şahıs ve mezhep nifakları ihdasına 
çalışarak ve bunda muvaffak olarak idarelerindeki ahenk ve muvazeneti ancak bu siyasetini idamesiyle temin edebilmiş olduklarından beynelmüslim şu siyaset neticesi olarak hasil olan tefrika-l cuyana ihtilafattan ve şahsi münaferetlerden dolayı yerlilerden elyevm bir kazada değil küçük bir nahiyede bile umum ahaliyi memnun edecek surette bi-tarafane bir idare takibine muktedir memur bulunması kâbil değildir. Bu itibarla nahiye müdüriyetlerine dahi taraf-l hükümetten müdürler tayin edilmesi ve hatta müdür-i yerliler bulunabilecek ise hiç olmazsa o nahiye ahalisinden olmasina bilhassa itina edilmesi lazım gelecektir. Zaten yerliler arasinda usul-u idaremiz kat'i nazar Türkçe tahrir ve kitabete bil-hakken vakıf kimseler dahi şimdilik bulunmadiğından mektep ve tecrübe ile bu cihet temin ve arz olunmasina nifak ve münaferetlerin iyi bir idare tahtında izalesine çalışlarak muvaffakiyet istihsal olunduktan sonra yerlilerden memur tayini imkanı hasıl olabilir.

Memurin-i mukteziyenin mevcut arasindan defaten intihab ve izamı hakikaten müteessir olduğundan bunun içinde ordularda müstahdem mekatib-i âliye mezunlarının hidmetlerinden istifade eylemek zaruridir. Başkumandanlık Vekâlet-i Celilerince bu babda mesbuk olan vaadin ifası halinde mesele bir dereceye kadar kesb-i suhulet eder.

Mahaza Elviye-i Selâse memurininin suret-i intihab ve tefrikinden ziyade emr-i izamında zirde arz olunduğu vechile şayan-ı tetkik birkaç mühim nokta vardır ki onların şimdiden hal edilmesi muktezidir:

Evvela- Gönderilecek memurların -Adliye, Maliye, İlmiye kısımları da beraber olduğu halde- hepsinin topluca izamiyla idare-i mülkiyenin tamam ve muntazam bir surette defaten tesisi lazımdır. Edevatı nakîs bir makinenin amelesi de noksan olmak tabii bulunmakla memurinin bir klsmi gidip de diğerlerinin azimeti herhangi sebeple düçar-ı tasdik olunduğu halde tesis olunacak idarenin bizden çok şeyler intizar etmekte olan sekene-i mahalliyeye karşı hükümeti aciz bir mevkide göstermekten başka tesiri olamayacağını oralardaki tetkikat ve müşahedat-ı zatiye-i acizaneme binaen arz eylerim.

Saniyen- Rus hükümeti en küçük memurlar için bile alamet-i mahsusayı havi elbise ve üniforma bit-tayin eksa ettirmis, ahali-i mahalliye bununla istinas ederek memurlara hürmet-i itiyad edinmiş olduğundan bizim tayin edeceğimiz memurların ve bilhassa nahiye müdürü ve kaymakamların da memuriyete mahsus alamet-i farikaya havi elbiseler iksâ etmesi zaruridir. Aksi takdirde bunların vakar-ı memuriyetleriyle mütenasip elbise tedarik eylemeleri bilhassa şu sırada gayr-i mümkün olmasına nazaran halka karşı hiss-i tesir göstermeyecek perişan ve pejmürde klyafetlerle ifa-ı vazife 
etmeleri icap eder ki bunun da mahâzîr-i adidesi derkârdır. Şu halde gidecek her memur için hükümetçe ikişer kat mücedded elbise yaptırllması vesair levazım-ı iksâiye tedariki esbabının istikmali lazım gelir.

Selâseten-Memurinin o havalide iaşesi son derecede müskil ve hatta maaşlarılyla kefâf- $ı$ nefs edecek kadar olsun yiyecek tedarik eylemeleri müstacel olduğundan ya cihet-i askeriye ile bil-itilaf memurinin iaşesine çalışılması veyahut yemek masrafi namıyla ayrıca tahsisat itası icap eder.

$B u$ cihetler temin olunamadiğ halde gönderilecek memurların idare-i mülkiyeyi tesis ve idamede muvaffakiyetleri meşkul olduğundan Elviye-i Selâse'de hal-i tabiyenin avdetine değin idarenin kemaken emr-i askeriye marifetiyle temini zaruridir. Memurin hakkindaki mülahazat-l vaka Elviye-i Selâse'de tesis olunacak idarenin temin-i mükemmeliyetine matuf olup fikr-i acizanemce bu livaların şarkta idare-i Osmaniye için bir numune-i ümran ve tekamül suretinde gösterilmesi siyaseten ve hakikaten pek müfid olacağından bu sureti ihzara vesile olacak esbabın temininde taraf-ı hükümet-i seniyyeden bil-hakken müzaheret olunmast icap eder.

Mahaza hükümet idaresi gerek memurin-i mülkiye ve gerek hitam-l harbe değin cihet-i askeriye marifetiyle tedvir edilmek Elviye-i Selâse'nin memalik-i asliye-i Osmaniyeye ilhakl akabinde kavain-i cariyemizden o havali için birdenbire gelecek olanların bir müddet sonra tatbikine başlanmak üzre tecil ahkâmını faideli görmekteyim. Ezcümle mükellefiyet-i askeriye kanunu bu kabildendir. Ruslar kark seneden beri ahali-i islamiyeyi askere almayacarak ana mukabil cüzî bir bedel-i askeri tahsiliyle iktifa etmişlerdi. Bu ahalinin idare-i osmaniyeye intikal edince derhal askere alınmaları hüsnü tesir ika edemez. Hatta milis teşkilatı namıyla Kars ve Ardahan dahilinde onyediden (17) elli (50) yaşına kadar sekene-i mahalliyenin bu defa muvakkaten askere davet edilmesi bile daha şimdiden nahoş karşılanmış idi. Sekene-i mahalliyenin hicret ve iltica vesair avartz-l harbiye dolayısıla duçar olduklarl ziyan-l maişete binaen tekalif-i maliyeden bir kısmının da tecile ihtiyaç görüleceğini zan etmekteyim. Zaten Elviye-i Selâse dahilinde arazi umumiyetle dağllk olup ziraata elverişli olarak Kars ve Ardahan ovalarından gayri münbit mahaller bulunmadığına ve diğer taraflarında da köylüler sadece haneleri için misır zıraatiyle me'lûf olarak hevaic-i sairelerini haricden tedarik eylediklerine binaen bu memleket müstahsil olmaktan ziyade müstehlik vaziyetinde bulunduğundan hükümet-i Osmaniye'ce Rusların yaptı̆ğ gibi oralardan varidat almak değil belki mesarif-i umumiye-i mahalliye için ayrıca para sarf etmek lazım gelecektir ki bu hal dahi hazine-i devletin tahsil edemeyeceği varidat-l cüziye için ahalinin tazyik edilmemesini icap ettirir. Filhakika Ruslar zamanında inşa edilen yolların ve mevcut ormanların hüsnü muhafazası ve 
dahil-i memlekette tesis ve temin edilen emniyet-i kat'iyyenin bundan sonra dahi idamesi ve elyevm hal-i atalette bulunan müessesat-l sanaiyyenin ihyast için hayli para sarfina ihtiyaç olup bunun da varidat-l mahalliye ile tesviyesi muhtemel bulunmadığından Elviye-i Selâse'nin arz olunan şerait dairesinde idaresi için Ruslarca olduğu gibi umumi bütçeden tahsisat itası taht'üllüzumiyettedir. Aksi takdirde birbuçuk senelik idareden bila-istifade köy ve kasabalardaki demir parmakliklara varmcaya kadar emval-i mevcudenin çalınıp nakline sebebiyet vermiş olan asayişsizliğin devamina ve tamir edilmemekten dolay bir hayli mahalleri şimdiden bozulmaya başlayan şoselerin ve memurin-i bekçi fikdanından naşi tahribata uğrayan ormanların tamamen harabiyetine cevaz verilmiş olur ki bu da herhalde hükümet-i seniyyenin matlubu hilafinda olduğundan şüphe yoktur. Binaenaleyh ilan-l ilhak akabinde Elviye-i Selâse'de idarenin tesisiyle tedabir-i ümraniyeye musırraten tevessül edilmesi muktezi ettiğinin arzına ve elviye-i mezkûrenin taksimat-ı idariyesini mübeyyin bir kita harita ile cetvelin takdimine müsaberet kılındı olbabda emr-i ferman hazret-i menleh-ül-emrindir ${ }^{31}$.

Dahiliye Nazırı İsmail Bey 7 Ağustos 1918'de Sadrazam Talat Paşa'y1 söz konusu rapor hakkında bilgilendirdiği üst yazıda; Abdülhalık Bey'in vurguladığ 1 gibi Rusların idari taksimatını kabul etmek zorunluluğundan hareketle Elviye-i Selâse'yi Batum ve Kars mıntıkalarına ayırarak iki vilayet veya müstakil sancağa dönüştürmeyi ve her ikisinin de Kafkas vilayetine bağlanmasını önerdi. İsmail Bey Ahılkelek, Ahıska, Iğdır ve Gümrü’nün birer müstakil mutasarrıflık halinde idare edilmesi durumunda ise bunların da aynı tarzda Kafkas vilayetine bağlanmasının uygun olacağını ifade etti. Nezaretin emrinde bölgenin ihtiyacını karşılamak üzere 21 kaymakam ve 90 nahiye müdürünün bulunmadığını, fakat devletin bütün memurları topluca göndererek mülki idareyi eksiksiz tesis etmesi gerektiğini itiraf ediyordu. Elbise ve iaşe sorunlarına da değinen İsmail Bey, bunların çözülmemesi durumunda mülki teşkilattan istenen başarının elde edilemeyeceğini savundu. Mülki teşkilatın kuruluşuna kadar idarenin asker marifetiyle teminini zaruri gören nazır, bölgenin ilhakını takiben ahalinin kendi düzenini kurmasına zaman kazandırmak üzere askere celp işlemlerinin bir müddet ertelenmesinin faydalı olacağını beyan etti ${ }^{32}$.

Abdülhalık Bey'in önerisine rağmen Dahiliye Nazırı'nın vergi muafiyeti ve genel bütçeden pay ayrılması gibi konulara değinmemesi

\footnotetext{
${ }^{31}$ BOA, DH/I-UM, 20-20/13-9.

${ }^{32}$ Dahiliye Nezareti'nden Sadarete 7 Ağustos 1334/1918 Tarihli Yazı. BOA, DH/İ-UM, 2020/13-9.
} 
nezaretin kendi sorumluluğunda olması hasebiyle önceliği mülki teşkilatın kurulmasına verdiğini göstermektedir.

Meclis-i Vükela 11 Ağustos 1918 'de toplanarak raporu ve nezaretin bununla ilgili tezkeresini gündemine aldı. Konu tartışılarak Elviye-i Selase'de görev alacak mülki kadronun Dahiliye Nezareti Müsteşarı'nın başkanlığında Adliye, Nafia, Maarif, Maliye, Ticaret ve Ziraat nezaretleri müsteşarlarından yahut aynı nezaretlere mensup daha alt düzey memurlardan teşkil edilecek bir heyet marifetiyle belirlenmesine karar verildi ${ }^{33}$. Dahiliye Nazırı İsmail Bey 14 Ağustos'ta Adliye, Nafia, Maarif, Maliye ve TicaretZiraat Nazırlarını karar hakkında bilgilendirerek adı geçen heyetin ayın 17. günü Dahiliye Nezareti'nde toplanacağını ve üye seçimlerinin o güne kadar tamamlanarak kendilerine bildirilmesini istedi ${ }^{34}$.

Heyetle ilgili hazırlıklar devam ederken Dahiliye Nazırı, 15 Ağustos'ta Sadrazam Talat Paşa'ya gönderdiği tezkerede bu güne kadar sadece mülki teşkilatın tesisi sorunuyla gündeme gelen Elviye-i Selâse'de geçmişte Rus yönetimiyle işbirliği yapan insanlara arazi tahsisinden kaynaklanan sorunların en az mülki teşkilat kadar önem arzettiğine dikkat çekti. Ayrıca mülki teşkilatın layıkıyla tesis edilebilmesinin söz konusu yanlışları düzeltmekte elzem olacağına işaret etti ${ }^{35}$. Dahiliye Nazırı'nın başvurusu 21

\footnotetext{
${ }^{33}$ BOA, MVM, 212/127.

${ }^{34}$ Dahiliye Nezareti'nden Maliye, Adliye, Nafia, Maarif ve Ticaret-Ziraat Nezaretleri'ne 14 Ağustos 1334/1918 Tarihli Tezkere. Bu talep doğrultusunda Maliye Nezareti adına Vekili Faik Bey, Ticaret ve Ziraat Nezareti adına Cemal Bey tayin edildi. BOA, DH/I-UM, 2020/13-9.

35 Dahiliye Nazırı İsmail Bey'in imzasıyla Sadarete gönderilen yazının tam metni şöyledir: "Nezaret-i aciz-i müsteşarı beyefendi tarafindan verilip leffen takdim kllınan raporun mütelasından müsteban olacağı üzre Elviye-i Selâse ahali-i asliyesi gerek ordumuzdan, gerek memurlarımızdan kendi saadet-i hal ve hüsn-ü akıbetleri namına pek çok şeylere intizar ve mutalib ve şikayet-i vakaları başlıca iki kısma inhisar etmekte olup bunlardan birincisi Rusya zamanında teneffüz eden vücuh-ı islamiyenin daire-i nüfuzlart dahilindeki dindaşlarına reva gördükleri mezalim alel-husus Rus inkilabına ve Elviye-i Selâse hükümetsiz kaldlktan sonra bu teneffuzatın icra ettikleri ve ettirdikleri yağmalara ve ikincisi de Rusların elde etmek istedikleri bazı mütenaffazatın arazi ve bağçeleri müstesna olmak üzere kurra ve kasabatta bilumum araziyi arazi-i haraciyeden add ile Islamların hukukunu iptal ve köylerde araziyi yalan matbua mukabilinde ahaliye icar ettiklerinden ve ancak bir güna verilen arazi o köyün heyet-i umumiyesi namina verilerek suret-i taksimi ahaliye terk olunmakla arazi meselesinde umumiyetle duçar olduklarl haksızlıklara dairdir. Birinci kısım erbab-ı şikâyet-i tebaanın izale-i nüfuzunu ve ikinci kısım ashabı da bu güne kadar muhafaza ettikleri tapular mucibince topraklarının kendilerine itasiyla Rusya zamanindaki haksı taksimatın tashihini talep etmekte vaktiyle muhacerete naşi bu kabil köylerde iskan ve emval-i metrukenin tevzii edilmesi gibi metalib dahi eksik olunmamakta olup ordu-ı hümayun harekât-ı askeriyenin devamıyla meşgul olmakta ve idare-i mülkiye tesisi için kafi derecede memur gönderilemediğinden naşi ne erbab-ı şikayetin metalibi ve ne de halkın ihtiyacatıyla
} 
Ağustos'ta Meclis-i Vükelâ'da “ evvel emirde Adliye ve Maliye nezaretleri memurlarından ve Şura-yı Devlet azasından birer zattan mürekkebin bir komisyon teşkili ile bil-etraf tedkikat icrası hususunda mahalline izamı..." münasip görülerek ${ }^{36}$, adı geçen heyetin başkanlığına Şura-yı Devlet Tanzimat Dairesi Reis-i Sanisi Saadettin Bey tayin edildi ${ }^{37}$.

Son komisyonla birlikte Elviye-i Selâse ile ilgili olarak birisi mülki teşkilatı ve kadroları tayin etmek üzere Dahiliye Nezareti Müsteşarı Abdülhalık Bey başkanlığında, diğeri ahalinin şikayetlerini araştırmak üzere Saadettin Bey başkanlığında iki komisyon oluşturuldu.

maatteessüf laylklyla iştigal edilememiştir. Bundan maada halk arasinda makbul olan erbab-l nüfuzun tefrikiyle haklarında hükümetçe ittihaz olunacak karara tevfikan muamele icrası lazım gelirken buna mugayir olarak Rusya zamanında temayüz eden bazı kimselere tarafimızdan da bir paye-i diğer ita edilmiş ve hatta bunlara ilaveten Rusya zamanında asker vermemiş olan ahali-i İslam'ın milis teşkilatı icra kılınacağı bahanesiyle 17 den 50 yaşına kadar olanların Kars, Ardahan ve Oltu havalisinde askere davet ve Ruslarn müsaade-i mahsusayla silahlarını taşımış olan köylülerin tüfenkleri derhal cem edilmiş sekene-i mahalliyenin arzusu hilafi cereyan şu ahval onlarm maneviyatında velev muvakkat olsun garip bir tereddüt hasıl eylemiștir. Tereddüt-i vakanın bir an evvel izalesiyle hükümet-i Osmaniye'nin İslamlara ve Íslamiye'ye her an ve zaman zahir olduğunun bir defa daha ispat edilmesi ve bunun için de Elviye-i Selâse'nin ilan-ı ilhakıyla hükümet-i mülkiyenin bir an evvel tesis edilmesi muvafik görülmektedir. Ancak tarz-l tesis ne derece olursa olsun onun için behemehâl hüsnü intihab edilmiş memurlara ihtiyaç derkârdır. Mahaza evvelsi raporlarda da zikredildiği vechile oralara gidecek memurinin her şeyden evvel iaşe, ilbas ve ihtiyacat-l nakdiyeleri temin ve tatmin edilmesi lazimeden olup aksi hal muhabereye mucip olacaktır. Bir de Ruslar hükümet ve memurlarını ahali-i İslamiye'ye karşı gayet azametli bir surette tesis-i vaka ederek hele klymet-i maneviyesini gayet büyük gösterdikleri nişanlardan herhangisiyle ledi'ül-icap bir şahsı en mühim makamında taltif etmiş olduklarından nişan ve madalya itasinda bizim de bu suretle hareketimiz ve taltif olunacak kimselerin hidmetlerini tedkik etmemiz zaruri olacaktır. Tedkik ve halli icap eden arazi meselesine müteallik tedkikat vali ve kaymakamların veya mahdut’ül-miktar maiyetleri marifetiyle ika olunamayacağından oralarda idare-i mülkiyenin tesisini müteakip gidecek memurlarla beraber maliye ve Ziraat nezaretleriyle defter-i hakani emanetine verilecek ehil ve vukuf birer memurlardan mürekkep olmak üzre bir heyet teşkiliyle münhasıran bu iş için izamı lazımdır. Bu heyetin kışın Batum ve mülhakatında, yazın Kars vilayetinde icra-ı devr ve tedkikat ederek tapulu, tapusuz arazi ve yayla ve meralar hakkında icap eden mikdaratı hiçbir tarafin şikayetini mucip olmayacak surette ittihaz eylerse hükümet için azim bir menfaat temin edilmiş olacaktır.”. Dahiliye Nezareti'nden Sadaret'e 15 Ağustos 1334 Tarihli Tezkere, BOA, DH/İ-UM, 20-20/13-9.

${ }^{36}$ BOA, MVM, 212/149.

${ }^{37}$ Saadettin Bey ve heyet üyelerinin harcırahları meselesi 29 Eylül'de Meclis-i Vükelâ'da görüşülerek; "...şimdilik avans olarak mesarif-i gayri melhuza tertibinden Saadettin Bey'e dörtyüzelli ve Esad Bey'e üçyüz lira ve aza-ı heyetten maliye ve adliye müfettișleri Ihsan ve Kenan beylere karar-ı sabık vechle beşer lira yevmiyenin tertib-i mezkûrdan verilmesi ve harcırahlarının da mensup oldukları nezaretlerin tertib-i mahsuslarından tesviyesi münasip görülmüştür" BOA, MVM, 212/191. 
Elviye-i Selâse'nin anavatana katılması ve mülki teşkilata ilişkin incelemelerin tamamlanarak raporun hazırlanması üzerine hükümet 11 Eylül 1918'de beş maddelik bir kararname yayınlayarak Elviye-i Selâse'deki mülki teşkilata nihai şekli verdi. Buna göre; Batum, Kars ve Ardahan ile mülhakatında Batum ve Kars livalarından mürekkep Batum vilayeti teşkil edildi. Dolayısıyla Abdülhalık Bey'in önerisi hükümet tarafından kabul görmüş ve sancaklar Batum vilayetine bağlı iki liva şeklinde teşkilatlandırılmış oldu ${ }^{38}$.

Dahiliye Müsteşarı Abdülhalık Bey'in başkanlığında tesis edilen yeni heyet Elviye-i Selâse'nin anavatana katılmasından yaklaşık bir hafta sonra, 21 Ağustos 1918 'de, Batum vilayeti mülki teşkilatının kadrosunu tertip etti. Nezaret aynı tarihli mazbatada öngörülen kadroların maaş zammı ve giyim vs. masraflarına mukabil üçyüz bin liralık tahsisat ayrılmasını öngören bir kararname hazırladı. Kararname hükümet tarafından uygun bulunsa da Meclis-i Vükela 29 Eylül 1918'de mezkûr kadro ve diğer teferruatların tatbikinin özel bir kararname tanzimine bağlı olduğuna ve söz konusu komisyonun Maliye Nezareti müsteşarının başkanlığında toplanarak icap eden layıhanın tertibine karar verdi ${ }^{39}$.

Maliye Nezareti, Elviye-i Selâse'ye gönderilecek memurların maaş, elbise ve harcırahlarıyla ilgili olarak asli maaşlarının üç, dört misli derecesinde tahsisat ile bir defaya mahsus elbise, kundura ve fes yardımı yapılmasına karar verdi. Fakat adı geçen memurların mezkûr livalara gönderilmesi ve vazifelerine başlattırılmaları hususunda tereddüt yaşanması üzerine Meclis-i Vükela, 6 Kasım'da mahallerine gönderilmelerinde zaruret olan memurların gönderilmesi, diğerlerinden ise sarfı nazar edilmesine karar vererek Maliye, Adliye, Maarif, Dahiliye, Nafia, Ticaret ve Ziraat nezaretlerini bilgilendirdi ${ }^{40}$.

Meclis-i Vükela'nın kararını takiben Maliye ile Dahiliye nezaretleri arasında görüşmeler başlatıldı. Maliye Nezareti 19 Kasım 1918'de Dahiliye Nezareti'ne gönderdiği tezkerede; "Batum ve Kars livalarına tayin ve izam olunacak memurinin maaş ve tahsisat- şehriyeleriyle masârîf-i seferiye-i hakikiyeleri 3 Teşrinievvel 334 tarihli kararnameye tevfikan maliye bütçesine mevzu tahsisat-l fevkaladeden verilmesi muktezi ise de bu babda hazinece tertib ve bir nüshası nezaret-i Celileleri muhabir müdiriyetine irsal kllınmış olan 4 Teşrinisani 334 tarihli talimatnamenin yedinci maddesi mucibince nev-i memuriyet ve miktar-ı maaş ile itası icab eden tahsisat-l

${ }^{38}$ GÖKDEMİR, Cenûbî Garbî Kafkas Hükümeti, s.23-24.

${ }^{39}$ BOA, MVM, 212/190.

${ }^{40}$ BOA, MVM, 213/4. 
şehriyye miktarını mübeyyen cetvelin bî-tanzim hazineye irsali hususunun icab edenlere emr ve havale buyurulması"nı istedi. 28 Aralı 1918'de Dahiliye Nezareti tarafindan verilen cevapta ise; "Batum mutasarrıfliğında altı bin guruş maaşla Cemil Bey bulunmakta ve Kars ve Ardahan'da da üç bin guruş maaşla Mülkiye Müfettişlerinden Mustafa Hilmi ve Asaf Talat Beyler idare-i mülkiye memurluğu vezâifini ifa eylemektedir. Ancak Batum vilayeti dâhilinde nezarete merbut olmak üzere polis ve jandarma gibi birçok memurin-i tâliye bulunduğundan bunların maaş ve mahsusatının da makamI mutasarrıftan sâlif-üz-zikr 4 Teşrinisani 334 tarihli talimatnamenin yedinci maddesine tevfikan muhasebeye verilecek defter üzerinden tesviyesi için Batum muhasebeciliğine emr-i ita ve keyfiyetin mutasarriflı̆̆a da inba buyurulması(nı)" talep etti ${ }^{41}$.

Hükümet bölgede görev alan ve alacak memurların maaşlarına zam yapmasına karşın Mondros Mütarekesi'nin gölgesinin devletin üzerine çöktüğü bir ortamda mülki idarede yaşanan sıkıntılar Kasım ayında iyice arttı. Mütarekenin 11. Maddesi Elviye-i Selâse'nin durumunu tartışmalı hale getirirken Osmanlı devleti lehine karar alınabilmesi için tam teşekküllü bir mülki idareye ihtiyaç vardı ${ }^{42}$. Kars Mutasarrıf Vekili Hilmi Bey 14 Kasım 1918'de Dahiliye Nezareti'ne gönderdiği telgrafta tam da bu noktaya dikkat çekmekteydi: "Liva mutasarrıfliğına tayin edildiği takaddüm ve fayda görülen Faik Bey'in bir ayı mütecaviz bir zaman geçtiği halde henüz hareketine dair bir haber alınamamıştır. Bu havalinin pek şedit olan kışı hulûl etmiş ve bir müddet sonra seyr-i sefer duçar-l tatil olarak memurinin gelebilmesi imkanı kalmayacağı tabii bulunmuş ve düvel-i itilafiyenin tedkikat icra edeceği bir sahada teşkilatın bir an evvel icra edilmiş bulunması lüzumu ise vareste-i arz ve beyan görülmüş olmağla mutasarrıf ve memurin-i sairinin acilen hareketleri esbabının istikmaline müsaade buyurulması maruzdur". Hilmi Bey'in dile getirdiği çözüm yolunda adım atılması gerekirken Dahiliye Nezareti'nin 19 Kasım'da "Faik Bey ve diğer memurların hareket zamanlarının tayini mümkün değildir" cevabı Elviye-i Selâse'nin kaderinin İtilaf devletlerinin insafina terk edileceğinin bir işareti gibiydi. Stratejik konumundan ötürü devletin görünen yüzünü temsil eden Batum'da da sıkıntı her geçen gün artmaktaydı. Batum Mutasarrıfı Cemil Bey 20 Kasım'da çaresizlik içinde kaza ve nahiyelere şimdiye kadar vazifesini müdrik memur gönderilememesi yüzünden işlerin yürütülemediğinden şikayet ederek kaymakamların ve iki aydır tayin oldukları bildirilen öğretmenlerin livaya gönderilmesini istemekten başka bir

\footnotetext{
${ }^{41}$ BOA, DH/I-UM, E/49-62.

${ }^{42}$ Geniş bilgi için bkz: Selçuk Ural, Mondros Mütarekesi ve Doğu Vilayetleri, İstanbul 2008, s.48-50.
} 
şey yapamayacaktı ${ }^{43}$. Sorun sadece kaymakam tayinleriyle sınırlı değildi. Dört ay önce tayin edildikleri bildirilen Telgraf Müfettişi Abdurrahman ve Muhasebeci Hilmi ve Muhabere Memuru Mustafa Reşit ve Kazım Efendilerin gelmemeleri üzerine adı geçen memurların kısa sürede Batum'a gönderilmeleri hususunda Dahiliye Nezareti nezdinde girişimde bulundu. Dahiliye Nezareti de 18 Aralık'ta Posta-Telgraf Nezareti'ne durumdan haberdar ederek söz konusu memurların gönderilmesini talep etti ${ }^{44}$.

Kars ve Batum livalarında ortaya çıkan sorunlardan biri de maaşların ödemelerinde aksamaların yaşanmasıydı. Aksaklığın iki nedeni bulunuyordu. Birincisi bazı mahallerde tahsisatın bulunmayışı, ikincisi ise maliye ile mülkiye arasında mevzuattan kaynaklanan uyuşmazlıklardı. Soruna ve sorunun kaynağına dikkat çeken ilkyazı 6 Kasım 1918'de Kars Mutasarrıf Vekili Hilmi Bey tarafindan kaleme alındı. Telgrafta; livaya muhasebeci gelmeden önce mahalli gelirlerin kendisi tarafindan toplandığını ve maaşlar dahil bütün masrafların bu paradan karşılandığını, muhasebecinin gelmesiyle birlikte işlerin ona bırakıldığını belirten Hilmi Bey, muhasebecinin havale ve tahsisat mevcut olmadığını gerekçe göstererek ödemeleri durdurduğunu, ordu veznesinin ise Batum vilayeti hakkındaki kararnamelerden kendilerine tebligat yapılmadığı için maaş vermediğini ve bundan dolayı memurların iki aydır maaş alamadığını ifade ederek veznesinde yeteri kadar para bulunan muhasebeciye veya Ordu Komutanlığı'na tebligatta bulunulmasını arz etti. Hilmi Bey 25 Kasım'da ise bölgeye mülkiyece başka ve maliyece başka nazarla bakılmasından dolayı işlerin karıştığını vurgulayarak nezaretler arasında uyumun sağlanması gerektiğine işaret etti. Hilmi Bey, 3 Aralık'ta durumu yeniden Dahiliye Nezareti'ne bildirmesi üzerine nezaret, iki gün sonra (5 Aralık 1918) Sadarete müracaat ederek Batum sancağına mensup memurların maaşlarının 9. Ordu tarafından ödenmesi için Harbiye Nezareti tarafından emir verildiğine dikkat çekerek Kars sancağı memurlarının gerek birikmiş iki aylık maaşlarının gerekse diğer maaş ve masraflarının ordu veznesinden 14 Eylül ve 3 Ekim 1918 tarihli kararnameler mucibince karşılanması hususunda Harbiye Nezareti'ne emir verilmesini talep etti. Hilmi Bey 9 Aralık'ta Dahiliye Nezareti'ne başvurarak 3 Ekim 1918 tarihli kararname dairesinde memurin maaşlarının ödenmesi için Maliye'ye yazıldığının kendisine bildirilmesine karşın henüz fiili bir sonucun alınmadığını, muhasebede ve orduda para mevcut iken şekli bir takım engellemeler yüzünden mülki idarenin zaafa uğratıldığını ve bütün masrafların 3.000 liralık bir mesele olduğunu belirterek tahsisatın tesviyesi için muhasebeye

\footnotetext{
${ }^{43}$ BOA, DH/İ-UM, 20-20/13-24.

${ }^{44}$ BOA, DH/İ-UM, 20-20/13-43.
} 
emir verilmesini veyahut ne tarz hareket edileceğinin bildirilmesini istedi. Batum Mutasarrıfı Mehmet Cemil Bey de 11 Aralık 1918'de Ekim ve Kasım maaşlarının ödenememesinin bilhassa polis ve jandarmada telafisi imkansız mahzurlar doğuracağını belirterek hem birikmiş maaşların hem de Aralık maaşlarının ödenebilmesi için gerekli havalenin yapılamasını talep etti. Dahiliye Nezareti aynı tarihte her iki mülki amirin şikayet ve taleplerini içeren tezkereyi Maliye Nezareti'ne göndererek söz konusu şikayetler hakkında Sadaret katında girişimde bulunulduğuna ve sonuçta maaş ve diğer masrafların ordu veznesinden karşılanmasına karar verildiğine ve bu hususta Harbiye Nezareti ile işbirliğine gidilerek keyfiyetin ilgili makamlara bildirilmesini rica etti. Dahiliye Nezareti 21 Aralık'ta Batum ve Kars sancaklarına maaşların düzenli şekilde tesviyesinin ordu tahsisatından karşılanmak üzere Harbiye Nezareti tarafından 9. Ordu Komutanlığı'na tebligatta bulunulduğunu bildirdi ${ }^{45}$.

26 Aralık 1918'de Ardahan'dan çekilen telgraf, yapılan bütün yazışmalara rağmen maaşların ödenmesi noktasında bir arpa yol alınamadığını gösteriyordu. Dahiliye Nezareti Ardahan Hükümet-i Mahalliye Riyasetinin telgrafina istinaden 29 Aralık'ta Maliye Nezareti'ne gönderdiği tezkerede "ait olduklart nezaretlerden tahsisat verilmedikçe memurin-i mülkiye ve jandarmanın maaşatı verilemeyeceği beyanıla tahsisatlarının ya hükümet namına irsali veya 9. Ordu namına itası için nezaret-i acizaneme müracaat edilmesi 9. Ordu tarafindan bildirildiğinden ve iki aydan beri maaş verilememiş olduğundan bahisle hükümet-i mahalliye riyaseti maaş ve jandarma maşatının ve müteferrika tahsisatının ve gelecek maha ait tahsisatın dahi Ardahan memurin-i mülkiye ve jandarmalar namına 9. Ordu'ya itası esbabının istikmaline Ardahan hükümet-i mahalliye riyasetinden alınan telgrafnamede lüzum gösterilmekle işaret-l sabıka muktezasinın tesrii ve neticeden malumat ita buyurulmasi(ni)" istedi ${ }^{46}$.

Yaklaşık iki ay boyunca maaşların düzenli şekilde ödenmesi için sergilenen çabalardan olumlu bir sonuç alınamamıştı. Mülki amirlerin de dikkat çektiği gibi maaşlarını alamayan memurlardan görevlerini layıkıyla yerine getireceklerini beklemek, hele hele mevcut şartlar altında ahalinin üzerinde olumlu bir etki yaratmak mümkün değildi.

\section{4- Ahalinin Şikâyet ve Beklentileri}

Mülki teşkilatın kurulması safhasında ahalinin de çeşitli beklenti ve şikâyetleri gündeme geldi. Bunların büyük kısmı Rusya zamanında ahalinin

\footnotetext{
${ }^{45}$ BOA, DH/İ-UM, 20-20/13-48.

${ }^{46} \mathrm{BOA}, \mathrm{DH} / \mathrm{I}-\mathrm{UM}, 20-20 / 13-47$.
} 
elinde bulunan bir miktar arazinin yönetimle işbirliği yapan insanlara dağıtılmasından kaynaklanan haksızlığın giderilmesine dayanıyordu. Şikâyetlerin diğer kısmı ise askeri makamların uygulama ve taleplerinden kaynaklanıyordu. Kurtuluşu takiben bölge ilk safhada askeri makamlar eliyle yönetilmeye başlanmış ve ordunun askeri harekâtı yürütmesini kolaylaştırmaya matuf uygulamaları doğal olarak halk arasında tereddüt ve şikâyetler doğurmuştur.

Ahalinin şikâyetleri ilk defa Abdülhalık Bey'in kaleme aldığı raporda yer alarak 30 Temmuz'da Meclis-i Vükela'nın dikkatine sunuldu. Bunu Dahiliye Nazırı İsmail Bey'in 15 Ağustos'ta Sadrazam Talat Paşa'ya hitaben kaleme aldığ 1 tezkere takip etti. İsmail Bey şikayetleri iki kısma ayırıp tarif ettikten sonra çözüm için öncelikle mülki teşkilatın mükemmel şekilde tesis edilmesini ve ilgili nezaretlerin temsilcilerinden oluşan bir heyetin bölgeye gönderilmesini önerdi:

“... Elviye-i Selâse ahali-i asliyesi gerek ordumuzdan, gerek memurlarımızdan kendi saadet-i hal ve hüsn-ü akıbetleri namına pek çok şeylere intizar ve mutalib ve şikayet-i vakaları başlıca iki kısma inhisar etmekte olup bunlardan birincisi Rusya zamanında teneffüz eden vücuh-l islamiyenin daire-i nüfuzlart dahilindeki dindaşlarına reva gördükleri mezalim alel-husus Rus inkılabına ve Elviye-i Selâse hükümetsiz kaldıktan sonra bu teneffuzatın icra ettikleri ve ettirdikleri yağmalara ve ikincisi de Rusların elde etmek istedikleri bazı mütenaffazatın arazi ve bağçeleri müstesna olmak üzere kurra ve kasabatta bilumum araziyi arazi-i haraciyeden add ile İslamların hukukunu iptal ve köylerde araziyi yalan matbua mukabilinde ahaliye icar ettiklerinden ve ancak bir güna verilen arazi o köyün heyet-i umumiyesi namina verilerek suret-i taksimi ahaliye terk olunmakla arazi meselesinde umumiyetle duçar oldukları haksızlıklara dairdir.

"Birinci klsım erbab-ı şikâyet-i tebaanın izale-i nüfuzunu ve ikinci klsım ashabı da bu güne kadar muhafaza ettikleri tapular mucibince topraklarının kendilerine itasıyla Rusya zamanındaki haksız taksimatın tashihini talep etmekte vaktiyle muhacerete naşi bu kabil köylerde iskân ve emval-i metrukenin tevzii edilmesi gibi metâlib dahi eksik olunmamakta olup ordu-ı hümayun harekât-ı askeriyenin devamıyla meşgul olmakta ve idare-i mülkiye tesisi için kâfi derecede memur gönderilemediğinden naşi ne erbab-l şikâyetin metâlibi ve ne de halkın ihtiyacatıyla maatteessüf layıkıyla iştigal edilememiştir.

"Bundan maada halk arasında makbul olan erbab-ı nüfuzun tefrikiyle haklarında hükümetçe ittihaz olunacak karara tevfikan muamele icrası lazım 
gelirken buna mugayir olarak Rusya zamanında temayüz eden bazı kimselere tarafimızdan da bir paye-i diğer ita edilmiş ve hatta bunlara ilaveten Rusya zamanında asker vermemiş olan ahali-i Islam'ın milis teșkilatı icra kılınacağı bahanesiyle 17 den 50 yașına kadar olanların Kars, Ardahan ve Oltu havalisinde askere davet ve Ruslartn müsaade-i mahsusayla silahlarını taşımış olan köylülerin tüfenkleri derhal cem edilmiş sekene-i mahalliyenin arzusu hilafi cereyan şu ahval onların maneviyatında velev muvakkat olsun garip bir tereddüt hasıl eylemiştir.

"Tereddüt-i vakanın bir an evvel izalesiyle hükümet-i Osmaniye'nin Íslamlara ve İslamiye'ye her an ve zaman zahir olduğunun bir defa daha ispat edilmesi ve bunun için de Elviye-i Selâse'nin ilan-ı ilhakıyla hükümet-i mülkiyenin bir an evvel tesis edilmesi muvafik görülmektedir. Ancak tarz-l tesis ne derece olursa olsun onun için behemehâl hüsnü intihab edilmiş memurlara ihtiyaç derkârdır... Tedkik ve halli icap eden arazi meselesine müteallik tedkikat vali ve kaymakamların veya mahdut'ül-miktar maiyetleri marifetiyle ika olunamayacağından oralarda idare-i mülkiyenin tesisini müteakip gidecek memurlarla beraber Maliye ve Ziraat nezaretleriyle defter-i hakani emanetine verilecek ehil ve vukuf birer memurlardan mürekkep olmak üzre bir heyet teşkiliyle münhasıran bu iş için izamı lazımdır...",47.

Askeri makamların uygulamaları çerçevesinde gündeme gelen bir başka konu ise "Tekâlif-i Harbiye" kapsamında aşar vergisi tahsili meselesiydi. Şark Orduları Grup Komutanlığı bölgede harekâtın devamını gerekçe göstererek Elviye-i Selâse'de elde edilecek hububattan sekizde bir öşür alınarak yemeklik, yemlik ve tohumluk ayrıldıktan sonra fazlasının askeri makamlarca satın alınması yönünde karar alınca Maliye Nezareti uygulamaya itiraz ederek konuyu Meclis-i Vükela'nın gündemine taşıdı. Nezaret 22 Mayıs 1918'de Batum Ardahan, Kağızman ve Oltu havalisinde 1918 yılı mahsulâtından ordunun iaşesini kolaylaştırmak üzere aşar vergisinden vazgeçilerek ahalinin tohumluk ve bir senelik iaşe ihtiyacının dışında kalan mahsulatın kâmilen halkın iaşesi adına satın alınmasının uygun olup olmayacağının Şark Orduları Grup Komutanlı̆̆ı'ndan sorularak kati muamelenin tayin edilmesini önerdi. Meclis-i Vükela 28 Ağustos 1918'de ordunun iaşesi meselesinin Harbiye Nezareti'nce tedkik olunmak üzere söz konusu livalar mahsulâtından aşar alınmaması hususunun Harbiye

\footnotetext{
47 Dahiliye Nazırı İsmail Bey'in önerdiği heyet 21 Ağustos 1918'de Meclis-i Vükela tarafindan oluşturuldu. BOA, DH/İ-UM, 20-20/13-9.
} 
Nezareti'ne tebliği ile Dâhiliye ve iaşe nezaretlerine malumat itasına karar verdi $^{48}$.

Mülki makamlar tarafindan gündeme getirilen arazi meselesi hakkında ahalinin de Dahiliye Nezareti ile Sadarete başvurdukları görülmüştür. 13 Ağustos 1918'de Oltu Muhacirleri Adına Hayri Beyzade Said tarafindan yapılan başvuruya herhangi bir cevap verilmeyince Hayri Beyzade Said 25 Ekim 1918'de yeniden Dahiliye Nezareti'ne ve Sadarete iki telgraf gönderdi. Telgraflarda; 93 Harbi neticesinde ellerindeki arazileri bedelsiz terk ederek Osmanlı topraklarına iltica ettikleri, Rus hükümetinin söz konusu arazileri devlet arazisine dönüştürerek gayri müslim ahaliyi yerleştirdiği ve bu nedenle kırk yıl boyunca sefalet içinde yaşadıklarına dikkat çekilerek Oltu'nun kurtarılmış olmasından dolayı topraklarının tapu kayıtları dikkate alınarak kendilerine iadesi talep edildi ${ }^{49}$.

Mülki ve askeri teşkilatların henüz kurulmakta olduğu göz önünde bulundurularak söz konusu teşkilatların yükünü artırmamak ve mevcut şikâyetlerin önüne geçebilmek maksadıyla Elviye-i Selâse'de geçici olarak $309,310,311$ ve 312 doğumluların askere alınmaması ve bunlara ilişkin tecil işlemlerinin askeri ve mülki makamlarca müştereken yapılmasına Meclis-i Vükela tarafindan karara bağlanarak Harbiye Nezareti bilgilendirildi ${ }^{50}$.

Askeri makamlar tarafindan kullanılan fakat belediyeye ait vergilerinin ödenmemesi bina sahipleri tarafindan şikayete konu edildi. Bu konuda mülki idareye yapılan başvurular üzerine Batum Mutasarrıfı Cemil Bey tarafından Dahiliye Nezareti'ne 12 Kasım 1918'de gönderilen telgrafta ordunun kira bedellerini vermediği halde kullanmaya devam ettiği binaların belediyeye ait vergileri ödenmediğinden dolayı elektrik ve sularının kesildiği ve bu durumun emlak sahiplerinin şikayetine neden olduğu belirtilerek sorunun en kısa sürede çözülmesi talep edildi ${ }^{51}$.

Ahalinin şikayet ve talepleri noktasında mülki ve askeri makamları meşgul eden konulardan biri de Elviye-i Selâse'deki malzemelerin Erzurum'a nakledilmesi sırasında ortaya çıktı. Kars gümrük ve ambarlarında bulunan erzak, halı, kilim ve manifatura gibi malzemelerin nakli Ekim ayı ortasında gündeme geldi. Dahiliye, Maliye ve Harbiye nezaretleri ile Sadaret

\footnotetext{
${ }^{48}$ BOA, MVM, 212/155.

49 Dahiliye Nezareti ve Sadarete 25 Ekim 1918'de Gönderilen Telgraflar. BOA, DH/İ-UM, 20-20/13-9.

50 Meclis-i Vükela'nın 10 Teşrin-i Sani 1334/10 Kasım 1918 Tarihli Kararı. BOA, MVM, 212/213.

${ }^{51}$ Dahiliye Nezareti 19 Kasım'da durumu Harbiye Nezareti'ne bildirerek gerekenin yapılarak sonucun bildirilmesini talep etti. BOA, DH/İ-UM, 20-20/13-23.
} 
arasında yürütülen görüşmelerin sonucunda malzemelerin Sarıamış üzerinden nakline karar verildi. 9. Ordu Komutanlığı öncelikle Brest-Litovsk Antlaşması'nın dışında kalan mahallerin tahliyesine ardından da söz konusu malzemenin sınır gerisine çekilmesi için memur edildi. Meclis-i Vükela 13 Kasım 1918'de nakledilecekler meyanında bulunan ve ahaliden toplandığ 1 muhtemel olan halı ve kilim vesaire eşyanın sahiplerine iadesine karar vererek Dahiliye Nezareti'ni bu konuyla ilgilenmekle görevlendirdi. Dahiliye Nezareti ile Erzurum Vilayeti arasında meydana gelen yazışmalar sonucunda söz konusu eşyanın iadesinin ancak Harbiye Nezareti'nin 9. Ordu'ya tebligatta bulunmasıyla mümkün olabileceği anlaşıldı. Dahiliye Nezareti'nin 18 Kasım'daki girişimi üzerine Harbiye Nezareti 26 Kasım'da 9. Ordu Komutanlığı'na gereken emri verdi. İşte tam bu noktada 9. Ordu Komutanının 1 Aralık'ta verdiği cevap bazı insanların yalan beyanlarla malzemeden pay kapmaya ve bunun için hükümeti ve nezaretleri yanlış yönlendirmeye çalıştıklarını ortaya çıkardı:

"Bu emval ve eşya hakkında Dersaadet'e mütemadiyen işaratta bulunarak muhabere kapılar açanlar ve Dersaadet'i muhtelif ve yanlış fikirlere sevk ve kararlar ve emirler itasina mecbur edenler kimler olduğunu bilsem bu mesele hakkinda daha kat'i ve daha doğru serd-i müteala eder ve nezaret-i celileyi daha iyi tenvir edebilirdim.

"Biz elviye-i mülhakayl harben işgal ederken ve ettikten sonra ambarlarda ve depolarda bulduğumuz emval ve eşyanın kâffesi Ruslara ve Rus ordularına ait şeylerdir... Elde edilen umum eşya meyanında yanlışlıkla veyahut ahali-i İslamiye'ye ait olarak zuhur eden emval ve eşya ve hayvanat sahipleri zuhur edip ispat eyledikçe kendilerine iade ve teslim edildi. Hatta bu meyanda Islam olanlar arasinda birçok yalancılar, dolandirıcılar zuhur etti. Hiristiyanlardan da şimdiye kadar yalnı bir Rus miralayının Kars kalesinde muhafiz ve bizce malum eşyası mumaileyhin müracaatı üzerine kendisine teslim olundu. Dahilde kalmış olan pek mahdut birkaç Rus ve malakan milletinden olan eşhassinda müracaat-l vakaları üzerine bazı eşyaları bulundu ve verildi.

"İşte şu vakadan maada sekiz aydır işbu eşyalar için başka ne sahipleri ve nede vasileri zuhur ve müracaat etmemiştir. Çünkü elviye-i mülhakada Batum'dan maada hiçbir yerde Ermeni kalmamıştı. Kâffesi firar ve hicret etmişti... Ve malum-ı devletleridir ki bir sandalyeye, bir pamuk çuvalına, bir arabaya bir kimse günün birinde sahip çıksa bunun hemen o talibe verilmesi doğru olamayacağ gibi böyle bir müracaatın ispat-ı hak etmesi de gayr-i mümkün derecede müşkildir. Binaenaleyh sekiz ay evvelde iğtinam ve cem edilmiş olan elde ne varsa bunların kâffesi Osmanlı ordusunun ve Osmanlı hükümetinindir. Elde edilmiş olan umum eşyadan eşya-ı askeri tedricen 
orduya sarf edilmiş ve edilmektedir. Eşya-ı adiyeden ordunun ve ordu ümera ve zabitaninin yine ihtiyacat-l resmiyesine lazım olanlar tayin olunan fiyat üzerinden ita ve sarf edilmiştir. Mütebaki eşya-ı adiyeden masa, sandalye, kilim, hall, lamba vesaire gibi bir kisım şeyler mahalli hükümetlerin, jandarmaların, sabit kıtaların açılklarına mazbatalarla verilmiştir. Bir kısım eşyada Erzurum'a naklolunmuştur ve olunmaktadir. Kendi ordum dahilde elde edilmiş olan bilumum mal ve eşyanın yağma ve zayi ve israf eylememiş olduğunu arz ve temin eylerim ${ }^{52}$.

\section{SONUÇ}

Elviye-i Selâse işgal yıllarında Rusya'nın askeri stratejisine uygun olarak bir değişim geçirdi. Türk ahalinin büyük acılara ve sefalete maruz kaldığ müslim unsurlar lehine bozuldu.

Çarlık yönetimi Birinci Dünya Savaşı'na girerken ezeli düşmanı olarak gördüğü Osmanlı Devleti’ni tarihten silmeyi planlarken toprakları içinde patlak veren Sosyalist devrim sonucunda ortadan kaldırıldı. Yeni hükümetin barış talebi Osmanlı hükümetine işgal altındaki toprakları kurtarma firsatı yaratt1. 3 Mart 1918'de imzalanan Brest-Litovsk Antlaşması'nın dördüncü maddesi sayesinde doğu vilayetlerine ek olarak Kars, Ardahan ve Batum'un da anavatana katılmasının yolu açıldı. Bu sayede Osmanlı devleti Kafkasya siyasetinde önemli aktörlerden biri haline geldi.

Osmanlı hükümetinin Elviye-i Selâse odaklı uygulamaları hiç kuşkusuz Kafkasya siyasetine de emsal teşkil edecekti. Mülki teşkilatın kurulması, müslim ve gayri müslim unsurların refahını ve güvenliğini artırmaya matuf adımları fevkalade önem taşıyordu. Fakat devletin savaştan ötürü maddi ve manevi gücü oldukça zayıflamıştı ve bu durum kendini mülki teşkilatın oluşturulmasında daha doğrusu oluşturulamamasında gösterdi. Çok sayıda kararname çıkarılmasına karşın üst düzeydekiler bir yana alt düzeyde nahiye müdürleri ve hatta gündelik işleri yürütecek memurların atanmaları mümkün olmadı. Mülki teşkilatların kurulması sorumluluğu halk oylamasını gerçekleştirmek üzere bölgeye gönderilen bir avuç mülkiye müfettişinin omzuna yüklendi. Marttan mütarekenin uygulanmaya başlandığı 1 Kasım'a kadar geçen 9 ay boyunca yerel yöneticilerin sayısız talep ve şikâyetleri nezaretlerin duvarlarında yankılandı ama bir sonuç alınamadı.

Hükümet halkın refahını korumak ve artırmak üzere birçok muafiyet kararı aldı. Bunlar ilk safhada hükümete ve yerel yönetimlere ayrıntılı

${ }^{52}$ BOA, DH/I-UM, 20-20/13-37. 
iktisadi programlar hazırlamak için zaman kazandırsa da geçen süre içinde bu konuda adımlar atılamadi.

Mülki teşkilat yönetimi devralıncaya kadar bölge askeri makamlar tarafindan idare edilmeye çalışıldı. Bu süre içinde halkın çeşitli şikâyet ve talepleri gündeme geldi. Bunlardan bir kısmı askeri makamların ordunun işlerini kolaylaştırmak amacıyla aldığ 1 kararlardan, büyük kısmı ise Rusya zamanındaki yanlış uygulamalardan kaynaklanıyordu. Askeri makamlardan kaynaklanan şikayetlerin düzeltilmesi kısa sürede mümkün olurken, arazi meselesi gibi başlangıcı eskiye dayanan sorunların çözümü mülki teşkilatın layıkıyla oluşturulamaması yüzünden mümkün olamadı.

\section{KAYNAKÇA}

\section{Telif Eserler}

ANWELLER, Oskar, Rusya'da Sovyetler (1905-1921), Çev: Temel Keşoğlu, İstanbul 1990

DAYI, Esin, Elviye-i Selâse'de (Kars, Ardahan, Batum,) Milli Teşkilatlanma, Erzurum 1997.

GÖKDEMIR, Ender, Cenûb-i Garbî Kafkas Hükümeti, Ankara 1989.

GÜNAY, Selçuk, Resmi Devlet Salnamelerine Gore Osmanlı İmparatorluğu'nun Seneler İtibariyle Mülki Teşkilatı, (Yayınlanmamış Yüksek Lisans Teri), Erzurum 1980.

KILIÇ, Selami, Türk-Sovyet İlişkilerinin Doğuşu, İstanbul 1998.

KIRZIOĞLU, Fahrettin, Kars Tarihi, İstanbul 1953.

KURAT, Akdes Nimet, Türkiye ve Rusya, Ankara 1990.

ORTAYLI, İlber, "Çarlık Rusyası Yönetiminde Kars", Tarih Enstitüsü Dergisi, Sayı: IX (Ayrı Basım), İstanbul 1978.

URAL, Selçuk, Mondros Mütarekesi ve Doğu Vilayetleri, İstanbul 2008.

\section{Gazeteler}

ATİ, 7 Mart 1334/1918, Nr: 66.

ATİ, 13 Mart 1334/1918, Nr: 72

ATİ, 6 Nisan 1334/1918, Nr: 96.

ATİ, 7 Nisan 1334/1918, Nr: 97. 
ATI, 16 Nisan 1334/1918, Nr: 106.

ATİ, 20 Nisan 1334/1918, Nr: 110.

ATİ, 27 Nisan 1334/1918, Nr:117.

SABAH, 16 Nisan 1334/1918, Nr:10208.

SABAH, 27 Nisan 1334/1918, Nr:10219.

SABAH, 29 May1s 1334/1918, Nr: 10251.

SABAH, 4 Haziran 1334/1918, Nr: 10256.

TANIN, 13 Mart 1334/1918, Nr: 3324.

TANIN, 16 Nisan 1334/1918, Nr: 3357.

VAKIT, 5 Mart 1334/1918. Nr:135.

VAKİT, 20 Nisan 1334/1918, Nr: 180.

\section{Arșiv Belgeleri}

BOA, Ali Fuat Türkgeldi'nin Mirasçılarından Satın Alınan Belgeler Kataloğu, 6-57.

BOA, DH/İ-UM, 20-18/12-74.

BOA, DH/I-UM, 20-18/12-24.

BOA, DH/İ-UM, 20-20/13-9.

BOA, DH/I-UM, 20-20/13-23.

BOA, DH/İ-UM, 20-20/13-24

BOA, DH/İ-UM, 20-20/13-29.

BOA, DH/İ-UM, 20-20/13-35.

BOA, DH/I-UM, 20-20/13-37.

BOA, DH/İ-UM, 20-20/13-43.

BOA, DH/İ-UM, 20-20/13-47.

BOA, DH/I-UM, 20-20/13-48.

BOA, DH/İ-UM, E/49-62.

BOA, HR. HMŞ. İŞO, 107/10.

BOA, MVM, 212/34.

BOA, MVM, 212/111.

BOA, MVM, 212/127. 
BOA, MVM, 212/149.

BOA, MVM, 212/155.

BOA, MVM, 212/190.

BOA, MVM, 212/191.

BOA, MVM, 212/213.

BOA, MVM, 213/4. 